\title{
Ülkelerin İnovasyon Performanslarının Ölçümünde Entropi ve MABAC Çok Kriterli Karar Verme Yöntemlerinin Bütünleşik Olarak Kullanılması
}

The Integrated Usage of Entropy and MABAC Multi Criteria DecisionMaking Methods for Measurement of Innovation Performance of Countries

Geliş tarihi: 19.01.2019, Kabul tarihi: 13.04.2019, Basım tarihi: 15.11.2019

\section{Öz}

Son y1llarda ülkelerin ekonomik olarak kalkınmışlık düzeyleri Ar-Ge, inovasyon, teknoloji ve bilime verdikleri değer ile yakından ilişkilidir. Bu nedenle ülkeler sürekli olarak inovasyon ekosistemini ve ekosistemde yer alan aktörlerin etkinliklerini arttırarak Ar-Ge ve inovasyon faaliyetlerini önemli ölçüde desteklemektedir. Bu çalışmada Entropi ve MABAC yöntemleri bütünleşik olarak kullanılarak ülkelerin inovasyon performansı ölçülmüştür. Entropi yöntemi ile kriterler ağırlıklandırılmış ve yenilikçilik, fikri varlıklar, finansman ve destekler değişkenlerinin en önemli kriterler olduğu belirlenmiştir. MABAC yöntemi ile de ülkelerin inovasyon performans değerleri hesaplanmıştır. İnovasyon performansı en yüksek olan ülkelerin İsviçre, İsveç ve Danimarka, en düşük olan ülkelerin ise Ukrayna, Romanya ve Makedonya olduğu sonucuna ulaşılmıştır.

Anahtar Kelimeler: Inovasyon Performansi, Entropi, MABAC, Cok Kriterli Karar Verme

JEL Kodlar1: C44, O31

\begin{abstract}
In recent years, economic development levels of countries are closely related to the $\mathrm{R} \& \mathrm{D}$, innovation, technology and science. For this reason, countries are constantly supporting the $\mathrm{R} \& \mathrm{D}$ and innovation activities by increasing the innovation ecosystem and the activities of the actors in the ecosystem. In this study, innovation performance of countries was measured by using Entropy and MABAC methods. The criteria are weighted by entropy method and innovators, intellectual assets, finance and support variables were the most important criteria. Innovation performance values of the countries were calculated by MABAC method. It is concluded that the countries with the highest performance of innovation are Switzerland, Sweden and Denmark, while the lowest countries are Ukraine, Romania and Macedonia.
\end{abstract}

\footnotetext{
${ }^{1}$ Kocaeli Üniversitesi İktisadi ve İdari Bilimler Fakültesi, Dr. Öğretim Üyesi ejder.aycin@kocaeli.edu.tr https:// orcid.org/0000-0002-0153-8430

${ }^{2}$ KOSGEB KOBİ Uzmanı, İzmir Kuzey Müdürlüğü, Dr.

enver.cakin@kosgeb.gov.tr

https:// orcid.org/0000-0001-7523-8193
} 
Keywords: Innovation Performance, Entropy, $M A B A C$, Multi Criteria Decision Making

JEL Codes: C44, O31

\section{Giriş}

Teknolojik gelişmeler ve küreselleşme ile birlikte ülkelerin güçlü ve sağlıklı ekonomilere ulaşmaları ve diğer ülkeler karşısındaki gelişmişlik düzeyleri sahip olduğu rekabet gücüne bağlıdır. Günümüz koşullarında ülkelerin elinde bulundurduğu en önemli güçlerden biri inovasyon konusunda edindiği deneyim, farklı ve yeni teknolojiler geliştirebilme yeteneğidir. Bu gücün önemini kavrayan ülkelerin bilim ve teknoloji politikalarının odak noktasını Ar-Ge ve inovasyon oluşturmaktadır. Ar-Ge faaliyetleri, ekonomide yenilik yaratabilmek için bilgi stokunda artış yoluyla teknolojik gelişmeleri sağlayan her türden yaratıcı nitelikteki sistematik aktivite olarak tanımlanabilir (Taş vd., 2017: 199). İnovasyon ise, Oslo Kılavuzu (2005)'nda, işletme içi uygulamalarda, işyeri organizasyonunda veya diş ilişkilerde yeni veya önemli derecede iyileştirilmiş bir ürün (mal veya hizmet) veya süreç, yeni bir pazarlama yöntemi ya da yeni bir organizasyonel yöntemin gerçekleştirilmesi olarak belirtilmektedir. $\mathrm{Bu}$ tanıma göre, inovasyon ürün, süreç, pazarlama ve organizasyonel inovasyon olmak üzere dörde ayrılmaktadır. İnovasyon hem ülkeler hem de firmalar için ulusal ve uluslararası alanda rekabet gücü kazanmanın, verimlilik artışı sağlamanın, ekonomik büyüme ve gelişmenin, dolayısıyla da refah ve yaşam kalitesi artışının en temel unsurlarından biri olarak kabul edilmektedir. OECD'nin saptamalarına göre, son 25 yılda özellikle gelişmiş ülkelerin ekonomik büyümelerinde inovasyon katkıs1 \%50'den fazladır (Işık ve Kılınç, 2011: 14).

Bir ülkede refah ve yaşam standartı rekabet gücü artarsa yükselir, rekabet gücü içinse üretkenliği arttırmak gerekir. Üretkenliği arttıran en önemli araç inovasyondur. Yapılan araştırmalar, ülkelerin belli bir süre, ihracat oranlarındaki iyiye gidiş veya iç talebin yüksekliği sayesinde büyüyebildiklerini; ancak bu büyümenin uzun vadeli ve sürdürülebilir olmasının ülkenin inovasyon performansına ve bu performanstaki artışa bağlı olduğunu ortaya koymaktadır (Elçi, 2007: 32). Ar-Ge çalışmaları ile ülkenin bilgi birikimi arttırılmakta ve bu bilgiler yeni uygulamalarda kullanılarak önemli rekabet avantajı elde edilebilmektedir. Daha sonra elde edilen bu yeni bilgiler var olan bilgiler ile birleştirilerek katma değeri yüksek inovatif ürünlere dönüştürülüp ülkelerin inovasyon performansları güçlendirilmektedir. İnovasyon ile ülkelerin refah seviyesi arttırılmakta, yeni iş ortamları oluşturulmakta, işsizlik ve ülkenin dişa bağımlılığı azaltılmaktadır. Bu nedenle ülkeler sürekli olarak Ar-Ge harcamalarını arttırarak yeni ürünler, hizmetler ve teknolojiler geliştirmek ve bu ürünlerini uluslararası pazarlarda satarak yüksek gelirler elde etmek istemektedirler. 
Ancak inovasyon için harcanan kaynakların etkin kullanılıp kullanılmadığının tespit edilebilmesi için ülkelerin düzenli olarak inovasyon performanslarının değerlendirilmesi gerekmektedir. Bununla birlikte inovasyon performansının ölçülmesi ile ülkeler diğer ülkeler arasındaki sıralamasını görebilmekte ve zayıf olan noktalarını gerekli önlemleri alarak güçlendirebilmektedir.

Çok kriterli karar verme (ÇKKV) yöntemleri, karar probleminde yer alan alternatifleri problem kapsamında belirlenen kriterler çerçevesinde kullanılan yöntemin teorik yapısına ve uygulama aşamalarına göre değerlendirerek en iyi ve en kötü alternatifleri belirlemektedir. ÇKKV yöntemleri, seçim, sıralama gibi birçok problemin çözümünde ve her alanda yaygın bir şekilde kullanılmaktadır. Bu çalışmada ÇKKV yöntemlerinden ülkelerin inovasyon performanslarının değerlendirilmesi sürecinde faydalanılabileceği düşünülmüştür. Entropi yöntemi ile kriterlerin ağırlıklandırılması ve elde edilen kriter ağıllıklarının MABAC yönteminde kullanılarak ülkelerin inovasyon performanslarının analiz edilmesi amaçlanmıştır. Literatür incelediğinde, ÇKKV yöntemi olarak AHP, ANP, TOPSIS, VIKOR, PROMETHEE gibi yöntemlerin yaygin bir şekilde kullanıldığı görülmektedir. Bunun yanında Entropi, MACBETH, Gri İlişkisel Analiz, MOORA, COPRAS gibi az kullanılan diğer ÇKKV yöntemlerinin uygulandığı çalışmalara da rastlamak mümkündür. Bu çalışma ile ayrıca ÇKKV yöntemleri arasında çok az kullanım alanı bulan yeni bir ÇKKV yöntemi olan MABAC yönteminin tanıtılması hedeflenmektedir. Bu düşünce ile ilk olarak konu ile ilgili ve çalışmada ele alınan yöntemlere ilişkin literatür taraması yapılmış olup, kullanılan yöntemlerin teorik çerçevesi incelenmiştir. Son bölümde ise ele alınan ÇKKV yöntemlerinin bütünleşik olarak kullanılarak inovasyon performansı ölçüm sürecindeki uygulamasına yer verilmiştir.

\section{Literatür Taraması}

Ülkelerin temel hedefleri ekonomik büyümeyi sürdürülebilir şekilde sağlamaktır. Bunun için ekonomik büyümenin dinamiklerine sahip olmak ve bunların doğru kullanarak geliştirmek gerekmektedir. Üretim faktörlerinin verimli olarak işlemesi ve üretim sürecine yansımasını sağlayan temel faktör ise teknolojidir. Teknolojinin gelişimi ise Ar-Ge faaliyetleri ile mümkün olabilmektedir. Ar-Ge harcamalarının arttırlması, üretim süreçlerinde kullanılan teknolojinin yeniliklerle güçlenmesini ve verimliliğinin arttırılmasını sağlamaktadır (Tiryakioğlu, 2006: 3). Ekonomik büyümenin sağlanmasında teknolojik gelişmeler etkili bir rol oynamaktadır. Teknolojik gelişmeler firmalar tarafindan yapılan Ar-Ge faaliyetleri sonucunda ortaya çıkmaktadır. Teknolojik yenilikler bir firmanın rekabet gücünü arttırıp pazar payının büyümesini sağladığı gibi karlılığın da artmasına katkıda bulunmaktadır. Teknolojik yenilik üretimde etkinlik sağlayarak kaynakların verimli kullanılmasını sağlamaktadır. Makro açıdan bakıldığında ise 
ekonomik büyümeyi hızlandırarak yaşam kalitesinin artmasında önemli bir faktördür (Korkmaz, 2010: 3321). Ayrıca Ar-Ge faaliyetleri teknolojik yeteneğe yaptığ1 katk1 sonucunda ülkeye doğrudan yabanc1 sermaye yatırımlarının girişini teşvik ederek teknoloji odaklı yatırımlar yapılmasını ve ülkenin teknolojik açıdan diğer ülkelere bağımlı olmamasını sağlamaktadır (Taş vd., 2017: 199).

Romer (1990), Grossman ve Helpman (1991) ile Aghion ve Howitt (1991) tarafindan geliştirilen içsel büyüme modellerinde teknolojik gelişmenin temelinde Ar-Ge faaliyetlerinin yer aldığ1 ve teknolojik gelişme sayesinde sinırlı kaynaklardan daha fazla katma değer üretimi ve uzun vadede büyüme gerçekleştiği belirtilmektedir (Bayraktutan ve Kethudaoğlu, 2017: 679-680). Literatürde Ar-Ge, teknolojik gelişme ve verimlilik arasındaki ilişkiyi inceleyen çeşitli çalışmalar mevcuttur. Griffith vd. (2004), panel veri analizi ile OECD ülkeleri üzerinde yaptıkları çalısmada Ar-Ge çalışmalarının teknolojinin gelişmesinde önemli rol oynadığını ortaya koymuşlardır. Apokin ve Ipatova (2016), Aydın ve Yalçınkaya (2016), Gömleksiz vd. (2017) ile Wakelin (2001) yaptıkları çalışmalarda Ar-Ge yatırımlarının verimlilik üzerindeki etkilerini incelemişler ve Ar-Ge'nin verimlilik üzerinde pozitif etkisi olduğu sonucuna ulaşmışlardır. Sadraoui ve Zina (2009) yaptıkları çalışmada dinamik panel veri analizi yöntemi ile 23 ülkenin 1992-2004 yılları arasındaki verilerini incelemişler ve Ar-Ge faaliyetlerinin ekonomik büyüme üzerinde anlamlı ve pozitif bir ilişkiye sahip olduğunu göstermişlerdir.

Ar-Ge faaliyetleri ile birlikte teknolojik gelişmeler sayesinde inovatif ürünler geliştirilerek rekabet avantaj1 elde edilebilmektedir. Ar-Ge faaliyetlerinin ticarileşmesi olarak ifade edilebilen inovasyon için önemli kaynaklar kullanılmakta ve bu kaynakların etkin kullanılıp kullanılmadığının tespiti ve hedeflere ulaşılıp ulaşılmadığının kontrol edilebilmesi için dönemsel olarak inovasyon performansının ölçülmesi gerekmektedir. Literatür incelendiğinde, birçok farklı nitel ve nicel kriterlerin dikkate alınarak ve birçok farklı yöntem kullanılarak inovasyon performansının ölçüldüğü çalışmalara rastlamak mümkündür. Katila (2000), yaptığ1 çalışmada biyoteknoloji işletmelerinin radikal performanslarını istatistiksel olarak ölçmüştür. Patent verilerinin ve atıf yapılan patentlerin inovasyon performansını ölçmede faydalı bir yöntem olduğunu vurgulamıştır. Ayrıca teknolojik iş birliği partnerlerinin sayısının radikal inovasyon ile doğrusal olmayan bir şekilde ilişkili olduğunu belirtmiştir. Hagedoorn ve Cloodt (2003), dört farklı yüksek teknoloji sektöründe faaliyet gösteren 1200 uluslararası büyük işletmenin inovasyon performansını istatistiksel olarak analiz etmişler ve sektörleri karşılaştırmalı olarak incelemişlerdir. Havacılık ve savunma, bilgisayar ve ofis makineleri, ilaç, elektronik ve iletişim sektörlerini, performans göstergeleri olarak da Ar-Ge harcamaları, patent sayıs1, patent referansları ve yeni ürünler değişkenlerini incelemişlerdir. 
Abbasi vd. (2010), Veri Zarflama Analizi ile ülkelerin inovasyon sisteminin etkinliklerini analiz etmişlerdir. Girdi değişkenleri olarak, Ar-Ge personeli sayısı, eğitim ve Ar-Ge harcamalanı, çıktı değişkenleri olarak patent, telif hakları, yüksek teknoloji ihracatı değişkenlerini ele almışlardır. Ayrıca Tobit ve Sıradan En Küçük Kareler yöntemi ile de etkinsizlik değişim olasıllğını araştırmışlardır.

Kijek ve Kijek (2010), basit toplamsal yöntem ve oran analizi ile AB ülkelerinin inovasyon performansını analiz etmişlerdir. Girdi değişkenleri olarak, eğitime yapılan harcamalar, Ar-Ge harcamaları, internet erişimi, bilim ve teknoloji alanındaki üniversite mezunu sayıs1, bilgi teknolojileri harcamaları, iletişim harcamaları, e-devlet online kullanımı gibi değişkenleri, çıktı değişkenleri olarak patent sayısı, yüksek teknoloji ihracatı, yeni ürün ve süreç sayısı ile yeni ürünlerden elde edilen satış gelirleri değişkenleri kullanılmıştır. Analizleri sonucunda, İskandinav ve Batı Avrupa ülkelerinin inovasyon performanslarının diğer $\mathrm{AB}$ ülkelerinden daha iyi olduğu sonucuna ulaşmışlardır. Chen vd. (2011), yaptıkları çalışmada Veri Zarflama Analizi ile ülkelerin inovasyon etkinliklerini araştırmışlardır. Girdi değişkenleri olarak, Ar-Ge işgücü ve Ar-Ge harcamaları değişkenlerini, çıktı değişkenleri olarak da patent sayısı, bilimsel yayın sayısı, telif hakk1 ve lisans ücretleri değişkenleri dikkate alınmıştır. Çalışmaları sonucunda, ülkelerin inovasyon performanslarının patent ve telif hakk1 bakımından benzer olduğunu ancak bilimsel yayın sayısı bakımından performansları arasında önemli farkll11klar olduğunu belirlemişlerdir. Zhuparova (2012), inovasyon performansının ölçülmesinde kullanılabilecek performans göstergelerini geliştirmiştir. İnovasyon performansı ölçümünde dikkate alınması gereken değişkenleri; inovasyon stratejisi ve inovasyon hedeflerin kalitesi, inovasyon kapasite düzeyi, yatırım miktarı, inovatif değişimler için kullanılan metotlar, firmaların rekabetçi durumu, inovasyon stratejilerini geliştirme ve uygulama hızı ve inovasyon faaliyetlerini uygulama düzeyi olmak üzere yedi ana değişken belirlemiştir. Çakır ve Perçin (2013), Entropi ve TOPSIS yöntemlerini bütünleşik olarak kullanarak $\mathrm{AB}$ ülkelerinin $\mathrm{Ar}-\mathrm{Ge}$ performanslarını ölçmüşlerdir. Çalışma kapsamında Ar-Ge yoğunluğu, araştırmacı sayısı, yükseköğrenimdeki brüt okullaşma oranı, yüksek teknoloji ihracatı, üçlü patent ailesi sayısı ve bilimsel yayın sayısı değişkenlerini analiz kapsamına almışlardır. Entropi yöntemi ile kriter ağırlıkları objektif bir şekilde hesaplanarak, TOPSIS yöntemi ile ülkelerin inovasyon performansları belirlenmiştir. Ghazinoory vd. (2014), yaptıkları çalışmada öğrenme ve teknoloji boşluğu kavramlarını kullanarak İran'daki bölgelerin inovasyon performansını ölçen bir model geliştirmişlerdir. Politikacılar için bölgelerin inovasyon performanslarının karşılaşıtıılmasının önemli olduğuna ve her bir bölgenin farklı tarihsel süreçleri ve coğrafik karakteristiklerinden dolayı kendine özgü inovasyon davranışlarının bulunduğuna dikkat çekmişlerdir. 
Konings ve Louw (2014), Yapısal Eşitlik Modeli ile Avrupa'daki ulaşım sektörünün bölgesel düzeyde inovasyon performanslarını ölçmüşlerdir. Avrupa'da yer alan 251 adet bölgenin verilerini dikkate alarak analizlerini gerçekleştirmişler ve Almanya ile İsveç'te yer alan bölgelerin inovasyon performanslarının daha iyi olduğunu tespit etmişlerdir. İnel ve Türker (2016), Avrupa İnovasyon Skorbordu verilerinden faydalanarak AHP ve TOPSIS yöntemleri ile birlikte ülkelerin inovasyon performansını ölçmüşlerdir. Çalışmada gayrisafi yurtiçi hasıla, gayrisafi yurtiçi hasıla içindeki Ar-Ge harcamaları ve kişi başına düşen patent sayısı olmak üzere üç temel kriter incelenmiştir. En önemli kriterin gayrisafi yurtiçi hasıla içindeki Ar-Ge harcaması olduğunu belirlemişlerdir. Roszko-Wojtowicz ve Bralek (2016), yaptıkları çalışmada $\mathrm{AB}$ üyesi ülkelerin inovasyon performansını Avrupa İnovasyon Skorbordu verilerinden faydalanarak kümeleme analizi yardımıyla ölçmüşlerdir. Avrupa İnovasyon Skorbordu kapsamında ele alınan mümkün kılıcılar, firma faaliyetleri ve çıtıılar olmak üzere üç ana değişkeni ele almışlardır. Mümkün kılıcılar ana değişseni altında insan kaynakları, açık araştırma sistemi, finans ve destekler alt değişkenlerini, firma faaliyeti ana değişkeni altında yatırımlar, bağlantılar ve girişimcilik, entelektüel sermaye alt değişkenlerini, çıktı ana değişkeni altında ise yenilikçiler ve ekonomik etkiler alt değişkenlerini kullanmışlardır.

Zizlavsky (2016), Çek Cumhuriyeti'nde imalat sanayinde faaliyet gösteren işletmelerin inovasyon performanslarını istatistiksel olarak analiz etmiştir. Analizleri sonucunda, ürün ve süreç inovasyonlarının, pazarlama ve organizasyonel inovasyonlardan daha fazla olduğunu ortaya koymuştur. Mavi ve Standing (2017), Veri Zarflama Analizi ile OECD ülkelerinin ekoinovasyon etkinliklerini analiz etmişlerdir. Girdi değişkenleri olarak, enerji ve çevre ile ilgili Ar-Ge harcamaları, Ar-Ge personel sayısı, yeşil yatırım sayısı, ISO 14001 organizasyon sayısı gibi değişkenleri, çıktı değişkenleri olarak da ekoloji ve çevre ile ilgili patent sayısı, akademik yayın sayısı gibi değişkenleri ele almışlardır. Çalışmalanı sonucunda, eko-inovasyon performansını arttırmada enerji kullanımı ve ekolojik sürdürülebilirliğin en önemli faktörler olduğunu belirlemişlerdir. Gault (2018), yaptığı çalışmada sistem yaklaşımı ile tüm ekonomik sektörlerde uygulanabilecek genel bir inovasyon tanımı ve inovasyonun ölçümü için kavramsal bir çerçeve geliştirmiştir. Önerdiği modelin inovasyon politikalarını değerlendirmede ve incelemede kullanılabileceğini ayrıca uluslararası karşılaştırmalarda da bu modelden yararlanılabileceğini belirtmiştir. Pop ve Pop (2018), Küresel İnovasyon Endeksi ve Avrupa İnovasyon Skorbordu olmak üzere iki farklı çalı̧mayı dikkate alarak Romanya'nın performansını teorik olarak ve karşılaştırmalı bir şekilde yıllar bazında analiz etmişlerdir.

Bu çalışmaların dışında çeşitli uluslararası kurum ve kuruluşlar tarafından her yil ya da belirli dönemlerde ülkelerin inovasyon performanslarının ölçüldüğü ve ülkelerin inovasyon performans indekslerinin hesaplandığ1 
çalışmalar mevcuttur. Avrupa İnovasyon Skorbordu $28 \mathrm{AB}$ üyesi ülke ve 8 tane de $\mathrm{AB}$ üyesi olmayan ülkelerin inovasyon performanslarını ölçmekte ve her yll düzenli olarak ülkelerin inovasyon indeksleri yayımlanmaktadır. Avrupa İnovasyon Skorbordu kapsamında insan kaynakları, açık araştırma sistemi, finans ve destek, firma yatırımları, bağlantılar ve girişimcilik, entelektüel varlıklar, yenilikçiler ve ekonomik etkiler ana değişkenleri kapsamında 25 farklı performans göstergesi dikkate alınmaktadır (European Innovation Scoreboard, 2016: 1-10). Makro çerçevede yapilan diğer çalışmalardan biri de Küresel İnovasyon Endeksidir. Bu endeks kapsamında girdi olarak kurumlar, insan kaynağı ve araştırma, altyap1, piyasa gelişmişliği ve iş dünyası gelişmişliği, çıktı olarak da bilimsel çıtıtlar ve yaratıcı çıktılar olmak üzere toplam 7 ana değişken alında 79 farklı alt değişken ele alınarak her yıl ülkelerin inovasyon endeksleri hesaplanmaktadır (Global Innovation Index, 2012).

Bu çalışmada Entropi yöntemi kriterlerin ağırlıklarının belirlenmesinde, MABAC yöntemi de ülkelerin inovasyon performansının ölçülmesinde kullanılmışır. Çalısma kapsamında incelenen bu çok kriterli karar verme yöntemlerinin farklı uygulama alanlarında kullanıldığ görülmektedir. Hung ve Chen (2009) yatırım değerlendirme sürecinde, Li vd. (2011) kömür madenlerinin güvenlik değerlendirilmesi sürecinde, Chaghooshi vd. (2012) endüstri robot sistemi seçim sürecinde, Zhang (2015) tedarikçi değerlendirme sürecinde, Ömürbek vd. (2016) firmaların performans değerlendirme sürecinde, Sar1 (2017) personel performans değerlendirme sürecinde, Chen (2017) yüksek teknoloji işletmelerinin inovasyon performansı değerlendirme sürecinde, Çatı (2017) futbol takımlarının finansal ve sportif etkinliklerinin değerlendirme sürecinde, Sar1 (2017) Ar-Ge projelerinin öncelik sıralamas1 sürecinde, Li vd. (2018) şehirlerin sürdürülebilir performansının değerlendirilmesi sürecinde kriterlerin ağırlıklandırılmasında Entropi yöntemini kullanmışlardır. Pamucar ve Girovic (2015) lojistik merkezlerinde nakliye ve taşıma kaynaklarının seçiminde, Bozanic vd. (2016) ve Gigovic vd. (2017) yer seçiminde, Xue vd. (2016) malzeme seçiminde, Yu vd. (2017) web sitelerinden faydalanarak otel seçiminde, Pamucar vd. (2018) yangin söndürme uçağı değerlendirmesinde ve Veskovic vd. (2018) yönetim modeli değerlendirmede MABAC yönteminden faydalanmışlardır.

\section{Entropi}

Entropi kavramı 1865 yllında Clausius tarafindan, termodinamikte düzensizlik ve dağınıklı̆ın bir ölçütü olarak literatüre giren bir kavramdır. Bu kavram Shannon (1948) tarafından kesikli olasılık dağılımı ile açıklanan belirsizliğin ölçüsü olarak farklı bir şekilde enformasyon teorisi açısından tanımlanmıştır (Zhang vd., 2011: 444). 
Birden çok kriteri içerisinde bulunduran karar verme problemlerinde, kriter ağırlıklarının hesaplanması oldukça önemli bir konudur. Entropi yöntemi literatürde yer alan ağırlık hesaplama yöntemlerinden objektif olanlar kategorisinde değerlendirilmektedir. Entropi yönteminde karar probleminde yer alan kriterlere ilişkin ağırlıklarının hesaplanması için, karar matrisindeki veriler kullanılmaktadır. Başka herhangi bir öznel değerlendirmeye ihtiyaç duyulmaması nedeniyle yöntemin uygulanabilirliği oldukça kolaydır. Entropi yöntemi beş aşamadan oluşan bir uygulama sürecine sahiptir (Erol ve Ferrell, 2009: 1196-1197; Wang ve Lee, 2009: 8982; Özdağoğlu vd..2017: 346-347; Vujičić vd., 2017: 425).

1. Aşama: Karar Matrisinin Oluşturulması: Yöntemin ilk aşamasında $x_{i j}$ değerlerinden oluşan ve $D$ ile simgelenen karar matrisi Eşitlik (1)'de gösterilen şekilde oluşturulur.

$$
D=\begin{gathered}
A_{1} \\
A_{2} \\
\vdots \\
A_{m}
\end{gathered}\left[\begin{array}{cccc}
x_{11} & x_{12} & \ldots & x_{1 n} \\
x_{21} & x_{22} & \ldots & x_{2 n} \\
\vdots & \vdots & \ldots & \vdots \\
x_{m 1} & x_{m 2} & \ldots & x_{m n}
\end{array}\right]
$$

Eşitlik (1)'de yer alan $x_{i j}$ değerleri, $j$. değerlendirme kriterine göre $i$. alternatifin aldığı değerleri göstermektedir ( $i$, karar alternatifi sayısı $i=$ $1,2, \ldots, m ; j$ ise değerlendirme kriteri sayıs $j=1,2, \ldots, n$ sayıs 1$)$.

2. Aşama: Karar Matrisinin Normalizasyonu: Karar problemlerinde yer alan farklı birimlere sahip kriterlere ait veriler, normalizasyon işlemiyle $[0,1]$ aralığında değer alacak şekilde standart bir hale getirilmelidir. Normalizasyon işlemi Eşitlik (2)'den yararlanılarak gerçekleştirilir.

$$
p_{i j}=\frac{x_{i j}}{\sum_{i=1}^{m} x_{i j}} \quad \forall i, j
$$

Eşitlik (2)'de yer alan $p_{i j}$ : değerleri, $j$. değerlendirme kriterine göre $i$. alternatifin aldığı normalize değeri göstermektedir.

3. Aşama: Entropi Değerlerinin Bulunmas1: Bu aşamada her bir değerlendirme kriterinin Entropi değerleri $\left(\boldsymbol{e}_{j}\right)$, Eşitlik (3)'te gösterilen şekilde hesaplanır.

$$
e_{i j}=-k \cdot \sum_{j=1}^{n} p_{i j} \cdot \ln \left(p_{i j}\right) \quad i=1,2, \ldots, m \text { ve } j=1,2, \ldots, n
$$


Eşitlik (3)'de yer alan $k$ değeri $k=(\ln (m))^{-1}$ olarak tanımlanan sabit bir katsayıdır ve $0 \leq e_{j} \leq 1$ olacak şekilde değer alır. $e_{j}$ değeri, $j$. kriterin belirsizlik ölçüsü olan Entropi değeri olarak tanımlanır.

4. Aşama: Farklılaşma Derecelerinin Bulunması: Bu aşamada, bir önceki aşamada hesaplanan Entropi değerleri kullanılarak, farklılaşma dereceleri olan $d_{j}$ değerleri her bir kriter için Eşitlik (4)'te gösterilen şekilde hesaplanir.

$$
d_{j}=1-e_{j} \quad j=1,2, \ldots, n
$$

5. Aşama: Entropi Kriter Ağırlıklarının Hesaplanması: Yöntemin son aşamasında her bir kriterin farklılaşma derecesini, toplam farklılaştırma derecesine oranlayarak kriterlerin ağırlık değerleri $\left(\mathrm{w}_{\mathrm{j}}\right)$ Eşitlik (5)'te gösterilen şekilde hesaplanır

$$
w_{j}=\frac{d_{j}}{\sum_{j=1}^{n} d_{j}}
$$

\section{MABAC}

$M A B A C$ (Multi-Attributive Border Approximation Area Comparison) yöntemi, Pamučar ve Ćirović tarafından literatüre kazandırılan bir ÇKKV yöntemidir (Pamučar ve Ćirović, 2015). MABAC yöntemi karar alternatiflerinin kriter fonksiyonlarının sınır yakınlık alanına uzaklıklarını dikkate alarak değerlendirme yapan bir yöntemdir (Milosavljevića vd., 2018; Pamučar vd., 2018). Öncelikle kriter fonksiyonlarının değerleri, her bir karar alternatifi için hesaplanır ve bu fonksiyonların sınır yakınlık alanına olan mesafeleri belirlenir. Daha sonra kriter fonksiyonlarının uzakliklarının belirlenmesiyle birlikte karar alternatifleri sıralanır ve en iyi alternatif seçilir (Pamučar ve Ćirović, 2015). MABAC yöntemi yedi aşamadan oluşan bir uygulama sürecine sahiptir (Pamučar ve Ćirović, 2015; Gigović vd., 2017; Pamucar vd. 2018):

1.Aşama: Başlang1ç Karar Matrisinin (X) Oluşturulması: $M A B A C$ yönteminde de ilk olarak $m$ adet karar alternatifi ve $n$ adet kriterden oluşan karar matrisi Eşitlik (6)'da gösterilen şekilde oluşturulur. Eşitlik (6)'da yer alan $x_{i j}$ değerleri, $j$. değerlendirme kriterine göre $i$. alternatifin aldığ değerleri göstermektedir. 


$$
X=\begin{gathered}
C_{1} \\
A_{1} \\
A_{2} \\
\ldots \\
A_{m}
\end{gathered}\left[\begin{array}{cccc}
x_{11} & x_{12} & \ldots & x_{1 n} \\
x_{21} & x_{22} & & x_{2 n} \\
\ldots & \ldots & \ldots & \ldots \\
x_{m 1} & x_{m 2} & \ldots & x_{m n}
\end{array}\right]
$$

2. Aşama: Karar matrisinin Normalizasyonu (N): Karar matrisinde yer alan farklı birimlere sahip kriterlere ait veriler, normalizasyon işlemiyle $[0,1]$ aralı̆̆ında değer alacak şekilde Eşitlik (7)'de gösterilen şekilde standart bir hale getirilmelidir.

$$
\begin{gathered}
C_{1} \\
A_{1} \\
A_{2} \\
A_{2} \\
\ldots \\
A_{m}
\end{gathered}\left[\begin{array}{cccc}
n_{11} & n_{12} & \ldots & n_{1 n} \\
n_{21} & n_{22} & & n_{2 n} \\
\ldots & \ldots & \ldots & \ldots \\
n_{m 1} & n_{m 2} & \ldots & n_{m n}
\end{array}\right]
$$

Normalizasyon işlemi maksimizasyon yönlü kriterler için Eşitlik (8), minimizasyon yönlü kriterler için Eşitlik (9)'dan yararlanılarak gerçekleştirilir.

$$
\begin{aligned}
& n_{i j}=\frac{x_{i j}-x_{i}^{-}}{x_{i}^{+}-x_{i}^{-}} \\
& n_{i j}=\frac{x_{i j}-x_{i}^{+}}{x_{i}^{-}-x_{i}^{+}}
\end{aligned}
$$

Eşitlik (8) ve (9)'da yer alan $x_{i}^{+}$değeri, sütunlarda yer alan maksimum değerleri; $x_{i}^{-}$değeri ise sütunlardaki minimum değerleri göstermektedir.

3. Aşama: Karar Matrisinin Ağırlıklandırılması: Bu aşamada kriter ağırlıkları Eşitlik (10)'dan yararlanılarak uygulama sürecine dahil edilir.

$$
v_{i j}=w_{i} \cdot\left(n_{i j}+1\right)
$$

4. Aşama: Sinır Yakınlı Alanı Matrisinin Oluşturulması: Bu aşamada tüm kriterler için Sımı Yakınlk Alam değerleri Eşitlik (11)'den yararlanilarak belirlenir. 


$$
g_{i}=\left(\prod_{j=1}^{m} v_{i j}\right)^{\frac{1}{m}}
$$

Eşitlik (11)'de yer alan $v_{i j}$ değerleri bir önceki aşamada hesaplanan ağırlıklandırılmış değerleri, $m$ ise karar alternatifi sayısını göstermektedir. Tüm kriterler için $g_{i}$ değerlerinin hesaplanmasıyla Eşitlik (12)'de gösterilen Simir Yakmllk. Alam Matrisi $(G)$ elde edilir.

$$
\left.G=\begin{array}{llll}
C_{1} & C_{2} & \ldots & C_{n} \\
g_{1} & g_{2} & \ldots & g_{n}
\end{array}\right]
$$

5. Aşama Karar Alternatiflerinin Sinır Yakınlı Alanına Olan Uzaklıklarının $(Q)$ Hesaplanması: Bu aşamada karar matrisindeki her bir değerin sınır yakınlık alanından uzaklıkları hesaplanarak Q matrisi Eşitlik (13)'d3 gösterilen şekilde elde edilir.

$$
Q=\left[\begin{array}{cccc}
q_{11} & q_{12} & \ldots & q_{1 n} \\
q_{21} & q_{22} & \ldots & q_{2 n} \\
\ldots & \ldots & \ldots & \ldots \\
q_{m 1} & q_{m 2} & \ldots & q_{m n}
\end{array}\right]
$$

Eşitlik (13)'de yer alan $q_{i j}$ değerleri, ağırlıklandırılmış karar matrisi elemanları ile ve sınır yakınlık matrisi elemanları arasındaki fark alınarak Eşitlik (14)'te gösterilen şekilde elde edilir.

$$
Q=V-G=\left[\begin{array}{cccc}
v_{11}-g_{1} & v_{12}-g_{2} & \ldots & v_{1 n}-g_{n} \\
v_{21}-g_{1} & v_{22}-g_{2} & \ldots & v_{2 n}-g_{n} \\
\ldots & \ldots & \ldots & \ldots \\
v_{m 1}-g_{1} & v_{m 2}-g_{2} & \ldots & v_{m n}-g_{n}
\end{array}\right]
$$

6. Aşama Karar Alternatiflerinin Sınır Yakınlı Alanına Göre Durumlarının Belirlenmesi: Bir önceki aşamadaki $q_{i j}$ değerlerine göre her karar alternatifi için $\left(A_{i}\right)$, sınır yakınlık alanına göre durumlar Eşitlik (15)'ten yararlanilarak belirlenir.

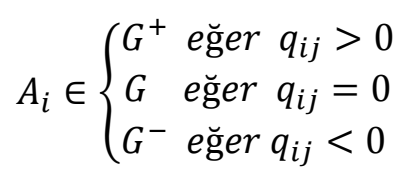


Eşitlik (15)'te gösterildiği üzere bir karar alternatifi, Sinır Yakınlı Alanmda $(G)$, Üst Yakmlık. Alaninda $\left(G^{+}\right)$ya da Alt Yakınlk. Alanmda $\left(G^{-}\right)$ yer alabilir. Bir karar alternatifinin en iyi alternatif olabilmesi için, kriterlere ilişkin değerlerinin çoğunun üst yakınlık alanında $\left(G^{+}\right)$bulunması gerekmektedir. $q_{i j}>0$ durumu $A_{i}$ alternatifinin ideal alternatife yakınlığını göstermekteyken; $q_{i j}<0$ durumu ise $A_{i}$ alternatifinin negatif-ideal alternatife yakınlığını göstermektedir.

7. Aşama. Karar Alternatiflerinin Sıralanması: Yöntemin son aşamasında karar alternatiflerin sınır yakınlık alanından uzaklık değerleri $\left(q_{i}\right)$ kullanılır ve Eşitlik (16)'dan yararlanılarak her karar alternatifinin kriter fonksiyonları hesaplanır.

$$
S_{i}=\sum_{j=1}^{n} q_{i j}, \quad j=1,2, \ldots, n, \quad i=1,2, \ldots, m
$$

\section{Uygulama}

Bu çalışmada Avrupa'da yer alan ülkelerin inovasyon performanslarının Entropi ve MABAC yöntemleri ile bütünleşik olarak ölçülmesi amaçlanmıştır. Bu doğrultuda, Avrupa Komisyonu tarafından geliştirilen ve $\mathrm{AB}$ üyesi ülkelerin karşılaştırmalı bir biçimde inovasyona dair çabalarını değerlendiren Avrupa İnovasyon Karnesi 2018 yll göstergelerinden yararlanılmıştır. Bu göstergelerin önemli bir bölümü Eurostat'tan alınan ham verilere dayanmaktadır. Avrupa İnovasyon Karnesi kapsamında yer alan ve çalışma kapsamında da inovasyon performansının değerlendirilmesi için dikkate alınan kriterler Tablo 1'de gösterilmiştir.

\section{Tablo 1. İnovasyon Performansı Değerlendirme Kriterleri}

\begin{tabular}{|l|l|}
\hline Kriter Kodu & Kriterler \\
\hline K1 & İnsan Kaynakları \\
\hline K2 & Araştırma Sistemleri \\
\hline K3 & İnovasyon Dostu Çevre \\
\hline K4 & Finansman ve Destekler \\
\hline K5 & Firma Yatırımları \\
\hline K6 & Yenilikçilik \\
\hline K7 & Bağlantılar \\
\hline K8 & Fikri Varlıklar \\
\hline K9 & İstihdam Etkisi \\
\hline K10 & Satışların Etkisi \\
\hline
\end{tabular}

Avrupa İnovasyon Karnesinde yer alan ve Tablo 1'deki kriterlere göre ülkelerin değerlendirilmesi ile oluşan veriler ise Tablo 2'de gösterilmiştir. 
Tablo 2. Çalışma Kapsamında Oluşturulan Karar Matrisi

\begin{tabular}{|c|c|c|c|c|c|c|c|c|c|c|}
\hline ÜLKE/KRİTER & K1 & K2 & K3 & K4 & K5 & K6 & K7 & K8 & K9 & K10 \\
\hline Belçika & 127,1 & 191,0 & 143,5 & 107,4 & 149,5 & 138,8 & 163,4 & 84,3 & 78,9 & 78,3 \\
\hline & 4,7 & 31,8 & 70,7 & 22,7 & 57,5 & 12,3 & 32,3 & 86,6 & 103,0 & 34,3 \\
\hline mhuriyeti & 93,5 & 82,4 & 106,0 & 50,9 & 116,2 & 74,1 & 78,4 & 63,2 & 115,7 & 98,7 \\
\hline Danimarka & 219,8 & 206,4 & 264,6 & 110,5 & 122,0 & 96,3 & 132,6 & 167,3 & 101,0 & 78,2 \\
\hline & 112,6 & 104,8 & 134,7 & 109,8 & 174,8 & 131,3 & 126,4 & 148,9 & 100,9 & 119,4 \\
\hline & 123,9 & 101,8 & 138,9 & 96,5 & 75,4 & 24,3 & 76,3 & 111,6 & 74,9 & 65,4 \\
\hline & 167,9 & 160,8 & 129,3 & 81,6 & 104,5 & 146,3 & 90,0 & 47,3 & 165,7 & 132,9 \\
\hline Yuna & 84,4 & 102,3 & 54,0 & 41,7 & 61,2 & 101,3 & 91,1 & 35,4 & 69,2 & 47,4 \\
\hline İsp & 141,6 & 98,7 & 143,5 & 86,4 & 75,8 & 36,2 & 69,3 & 72,9 & 90,7 & 76,6 \\
\hline & 48,5 & 146,8 & 135,8 & 152,2 & 97,9 & 104,4 & 102,4 & 86,8 & 92,5 & 109,6 \\
\hline & 53,7 & 42,3 & 54,4 & 40,2 & 108,1 & 62,0 & 67,2 & 29,8 & 69,0 & 26,7 \\
\hline İtalya & 65,2 & 99,4 & 84,6 & 59,4 & 64,5 & 90,8 & 57,1 & 104,3 & 74,8 & 77,0 \\
\hline & 14,2 & 118,7 & 61,0 & 45,8 & 60,6 & 87,0 & 60,4 & 115,5 & 61,1 & 76,1 \\
\hline & 79,8 & 55,8 & 141,2 & 107,4 & 37,5 & 12,7 & 44,3 & 48,8 & 94,1 & 46,3 \\
\hline Litvanya & 115,5 & 39,5 & 164,5 & 64,0 & 104,2 & 79,7 & 103,0 & 51,5 & 39,6 & 36,6 \\
\hline & 50,3 & 224,8 & 192,0 & 134,3 & 77,1 & 122,3 & 62,8 & 154,4 & 139,4 & 88,2 \\
\hline & 54,6 & 66,4 & 117,9 & 50,0 & 87,5 & 15,1 & 70,2 & 39,5 & 124,9 & 99,0 \\
\hline Malta & 66,5 & 161,0 & 165,4 & 7,5 & 79,8 & 67,9 & 11,9 & 168,3 & 140,5 & 56,8 \\
\hline Hollat & 174,4 & 207,5 & 213,3 & 140,2 & 85,4 & 109,5 & 152,6 & 127,7 & 115,9 & 95,5 \\
\hline & 134,6 & 157,4 & 116,0 & 98,8 & 150,7 & 122,1 & 144,9 & 147,5 & 66,0 & 82,8 \\
\hline Polonya & 72,2 & 33,4 & 127,2 & 33,2 & 90,6 & 2,9 & 37,9 & 75,2 & 92,5 & 55,3 \\
\hline Portekiz & 100,0 & 120,9 & 178,2 & 70,1 & 83,5 & 99,9 & 54,9 & 74,0 & 82,8 & 44,9 \\
\hline Romanya & 22,5 & 29,7 & 96,8 & 22,4 & 13,3 & 0,01 & 38,1 & 22,5 & 34,7 & 66,6 \\
\hline & 171,4 & 102,5 & 117,3 & 36,0 & 135,3 & 82,2 & 113,4 & 80,9 & 75,8 & 78,1 \\
\hline & 92,6 & 57,4 & 79,3 & 29,7 & 63,7 & 29,2 & 68,7 & 35,6 & 119,2 & 105,4 \\
\hline Finlandiya & 197,1 & 156,6 & 245,7 & 118,7 & 148,1 & 121,7 & 133,9 & 148,1 & 83,9 & 80,8 \\
\hline İsveç & 214,3 & 200,6 & 254,8 & 120,1 & 176,5 & 109,1 & 132,3 & 158,0 & 132,1 & 85,5 \\
\hline Birleşik K & 180,6 & 196,8 & 123,4 & 115,8 & 113,9 & 85,6 & 134,8 & 82,3 & 144,8 & 128,3 \\
\hline İzlanda & 150,3 & 188,1 & 264,6 & 122,3 & 134,5 & 123,6 & 158,2 & 57,8 & 147,1 & 36,6 \\
\hline İsrail & 105,1 & 130,6 & 112,3 & 45,6 & 243,9 & 74,6 & 141,2 & 103,2 & 186,1 & 95,9 \\
\hline Makedonya & 42,8 & 76,2 & 53,7 & 32,8 & 69,7 & 55,0 & 44,1 & 14,3 & 6,5 & 46,3 \\
\hline Norveç & 171,1 & 166,4 & 192,7 & 147,0 & 139,6 & 119,7 & 137,5 & 45,2 & 95,4 & 51,9 \\
\hline Sirbistan & 76,5 & 37,2 & 24,8 & 40,6 & 132,3 & 72,3 & 94,9 & 24,4 & 94,0 & 60,9 \\
\hline İsviçre & 236,4 & 251,6 & 193,9 & 126,4 & 234,8 & 160,7 & 142,1 & 164,7 & 118,1 & 114,6 \\
\hline Ukrayna & 131,6 & 22,3 & 5,5 & 16,7 & 44,8 & 16,0 & 9,6 & 13,4 & 77,9 & 32,8 \\
\hline Türkiye & 37,5 & 43,3 & 112,5 & 56,7 & 140,8 & 83,8 & 64,3 & 9,0 & 10,8 & 55,9 \\
\hline
\end{tabular}




\subsection{Entropi Yöntemi İle Kriterlerin Ağırlıklarının Bulunması}

Entropi yöntemi ile kriterlerin ağırlıklarının hesaplanabilmesi için öncelikle Tablo 2'de yer alan karar matrisi Essitlik (2)'den yararlanılarak normalize edilir. Normalize edilmiş karar matrisi Tablo 3 'te gösterilmiştir.

\section{Tablo 3. Normalize Edilmiş Karar Matrisi}

\begin{tabular}{|c|c|c|c|c|c|c|c|c|c|c|}
\hline ER & K1 & K2 & K3 & K4 & K5 & K6 & K7 & K8 & K9 & K10 \\
\hline & 0,030 & 0,045 & 0,030 & 0,039 & 0,039 & 0,048 & 0,050 & 0,028 & 0,023 & 0,029 \\
\hline & 0,015 & 0,008 & 0,015 & 0,008 & 0,015 & 0,004 & 0,010 & 0,029 & 0,030 & 0,013 \\
\hline Çek C & 0,022 & 0,020 & 022 & 0,019 & 0,030 & 0,026 & 0,024 & 0,021 & 0,034 & 0,037 \\
\hline Danin & 0,051 & 0,049 & 0,055 & 0,040 & 0,032 & 0,034 & 0,041 & 0,056 & 0,030 & 0,029 \\
\hline & 0,026 & 0,025 & 0,028 & 0,040 & 0,045 & 0,046 & 0,039 & 0,050 & 0,030 & 0,045 \\
\hline & 0,029 & 0,024 & 0,029 & 0,035 & 0,020 & 0,008 & 0,024 & 0,037 & 0,022 & 0,025 \\
\hline İrlanda & 0,039 & 0,038 & 0,027 & 0,030 & 0,027 & 0,051 & 0,028 & 0,016 & 0,048 & 0,050 \\
\hline Yunanistan & 0,020 & 0,024 & 011 & 0,015 & 0,016 & 0,035 & 0,028 & 0,012 & 0,020 & 0,018 \\
\hline & 0,033 & 0,023 & 0,030 & 0,032 & 0,020 & 0,013 & 0,021 & 0,024 & 0,027 & 0,029 \\
\hline & 0,035 & 0,035 & 028 & 0,056 & 0,025 & 0,036 & 0,032 & 0,029 & 0,027 & 0,041 \\
\hline Hirva & 0,013 & 0,010 & 011 & 0,015 & 0,028 & 0,022 & 0,021 & 0,010 & 0,020 & 0,010 \\
\hline İtalya & 0,015 & 0,024 & 0,018 & \begin{tabular}{|l|}
0,022 \\
\end{tabular} & 0,017 & 0,032 & 0,018 & 0,035 & 0,022 & 0,029 \\
\hline & 0,027 & 0,028 & 0,013 & 0,017 & 0,016 & 0,030 & 0,019 & 0,038 & 0,018 & 0,029 \\
\hline Leto & 0,019 & 0,013 & 0,029 & 0,039 & 0,010 & 0,004 & 0,014 & 0,016 & 0,028 & 0,017 \\
\hline Litvanya & 0,027 & 0,009 & 0,034 & 0,023 & 0,027 & 0,028 & 0,032 & 0,017 & 0,012 & 0,014 \\
\hline & 0,035 & 0,053 & 0,040 & 0,049 & 0,020 & 0,043 & 0,019 & 0,051 & 0,041 & 0,033 \\
\hline Macaris & 0,013 & 0,016 & 0,024 & 0,018 & 0,023 & 0,005 & 0,022 & 0,013 & 0,037 & 0,037 \\
\hline Malta & 0,015 & 0,038 & 0,034 & 0,003 & 0,021 & 0,024 & 0,004 & 0,056 & 0,041 & 0,021 \\
\hline & 0,041 & 0,049 & 0,044 & 0,051 & 0,022 & 0,038 & 0,047 & 0,043 & 0,034 & 0,036 \\
\hline & 0,031 & 0,037 & 0,024 & 0,036 & 0,039 & 0,043 & 0,045 & 0,049 & 0,019 & 0,031 \\
\hline Polonya & 0,017 & 0,008 & 0,026 & 0,012 & 0,023 & 0,001 & 0,012 & 0,025 & 0,027 & 0,021 \\
\hline Portekiz & 0,023 & 0,029 & 0,037 & 0,026 & 0,022 & 0,035 & 0,017 & 0,025 & 0,024 & 0,017 \\
\hline Romanya & 0,005 & 0,007 & 0,020 & 0,008 & 0,003 & 0,000 & 0,012 & 0,008 & 0,010 & 0,025 \\
\hline & 0,040 & 0,024 & 0,024 & 0,013 & 0,035 & 0,029 & 0,035 & 0,027 & 0,022 & 0,029 \\
\hline & 0,022 & 0,014 & 0,016 & 0,011 & 0,017 & 0,010 & 0,021 & 0,012 & 0,035 & 0,040 \\
\hline & 0,046 & 0,037 & 0,051 & 0,043 & 0,038 & 0,042 & 0,041 & 0,049 & 0,025 & 0,030 \\
\hline İsveç & 0,050 & 0,048 & 0,053 & 0,044 & 0,046 & 0,038 & 0,041 & 0,053 & 0,039 & 0,032 \\
\hline & 0,042 & 0,047 & 0,026 & 0,042 & 0,030 & 0,030 & 0,042 & 0,027 & 0,042 & 0,048 \\
\hline & 0,035 & 0,045 & 0,055 & 0,045 & 0,035 & 0,043 & 0,049 & 0,019 & 0,043 & 0,014 \\
\hline İsrail & 0,024 & 0,031 & 0,023 & 0,017 & 0,063 & 0,026 & 0,044 & 0,034 & 0,054 & 0,036 \\
\hline Mak & 0,010 & 0,018 & 0,011 & 0,012 & 0,018 & 0,019 & 0,014 & 0,005 & 0,002 & 0,017 \\
\hline & 0,040 & 0,039 & 0,040 & 0,054 & 0,036 & 0,042 & 0,042 & 0,015 & 0,028 & 0,019 \\
\hline & 0,018 & 0,009 & 0,005 & 0,015 & 0,034 & 0,025 & 0,029 & 0,008 & 0,027 & 0,023 \\
\hline & 0,055 & 0,060 & 0,040 & 0,046 & 0,061 & 0,056 & 0,044 & 0,055 & 0,035 & 0,043 \\
\hline Ukrayna & 0,031 & 0,005 & 0,001 & 0,006 & 0,012 & 0,006 & 0,003 & 0,004 & 0,023 & 0,012 \\
\hline
\end{tabular}




\begin{tabular}{|l|l|l|l|l|l|l|l|l|l|l|}
\hline Türkiye & 0,009 & 0,010 & 0,023 & 0,021 & 0,037 & 0,029 & 0,020 & 0,003 & 0,003 & 0,021 \\
\hline
\end{tabular}

Bir sonraki aşamada Eşitlik (3)'ten yararlanılarak, Tablo 3'de hesaplanan normalize edilmiş değerler $\left(p_{i j}\right)$ ile bu değerlerin logaritma değerleri $\left(\ln \left(p_{i j}\right)\right)$ birbirleriyle çarpılıp, toplanır. Eşitlik (3)'de yer alan $\mathrm{k}$ değeri ise karar alternatifi sayısının logaritması alınarak hesaplanmaktadır. Uygulamada otuz altı tane ülke yer aldığından dolayı bu değer, $k=(\ln (m))^{-1}$ formülünden yararlanılarak $k=(\ln (36))^{-1}=0,2791$ olarak hesaplanır. Elde edilen Entropi değerleri $\left(e_{j}\right)$ Tablo 4'te gösterilmiştir.

\section{Tablo 4. Entropi Değerlerinin Elde Edilmesi}

\begin{tabular}{|c|c|c|c|c|c|c|c|c|c|c|}
\hline ÜLKE/KRİTER & K1 & K2 & K3 & K4 & K5 & K6 & K7 & K8 & K9 & K10 \\
\hline Belçika & $-0,104$ & $-0,140$ & $-0,105$ & $-0,127$ & $-0,126$ & $-0,146$ & $-0,151$ & $-0,100$ & $-0,087$ & $-0,104$ \\
\hline Bulgaristan & $-0,063$ & $-0,037$ & $-0,062$ & $-0,040$ & $-0,063$ & $-0,023$ & $-0,046$ & $-0,102$ & $-0,105$ & $-0,056$ \\
\hline Çek Cumhuriyeti & $-0,083$ & $-0,077$ & $-0,084$ & $-0,074$ & $-0,106$ & $-0,094$ & $-0,090$ & $-0,081$ & $-0,115$ & $-0,122$ \\
\hline Danimarka & $-0,152$ & $-0,148$ & $-0,159$ & $-0,129$ & $-0,109$ & $-0,114$ & $-0,131$ & $-0,161$ & $-0,104$ & $-0,104$ \\
\hline Almanya & $-0,095$ & $-0,092$ & $-0,100$ & $-0,129$ & $-0,140$ & $-0,141$ & $-0,126$ & $-0,149$ & $-0,104$ & $-0,139$ \\
\hline Estonya & $-0,102$ & $-0,090$ & $-0,102$ & $-0,118$ & $-0,077$ & $-0,040$ & $-0,088$ & $-0,122$ & $-0,084$ & $-0,091$ \\
\hline İrlanda & $-0,127$ & $-0,125$ & $-0,097$ & $-0,105$ & $-0,098$ & $-0,152$ & $-0,099$ & $-0,065$ & $-0,147$ & $-0,150$ \\
\hline Yunanistan & $-0,077$ & $-0,090$ & $-0,050$ & $-0,064$ & $-0,066$ & $-0,118$ & $-0,100$ & $-0,052$ & $-0,079$ & $-0,072$ \\
\hline İspanya & $-0,112$ & $-0,088$ & $-0,105$ & $-0,109$ & $-0,077$ & $-0,055$ & $-0,082$ & $-0,090$ & $-0,096$ & $-0,102$ \\
\hline Fransa & $-0,116$ & $-0,117$ & $-0,101$ & $-0,161$ & $-0,093$ & $-0,121$ & $-0,109$ & $-0,102$ & $-0,098$ & $-0,131$ \\
\hline Hirvatistan & $-0,055$ & $-0,046$ & $-0,051$ & $-0,062$ & $-0,100$ & $-0,083$ & $-0,080$ & $-0,046$ & $-0,079$ & $-0,046$ \\
\hline İtalya & $-0,064$ & $-0,088$ & $-0,071$ & $-0,083$ & $-0,068$ & $-0,109$ & $-0,071$ & $-0,117$ & $-0,084$ & $-0,102$ \\
\hline Kibris & $-0,096$ & $-0,101$ & $-0,055$ & $-0,068$ & $-0,065$ & $-0,106$ & $-0,074$ & $-0,125$ & $-0,072$ & $-0,102$ \\
\hline Letonya & $-0,074$ & $-0,057$ & $-0,104$ & $-0,127$ & $-0,045$ & $-0,024$ & $-0,059$ & $-0,067$ & $-0,099$ & $-0,070$ \\
\hline Litvanya & $-0,097$ & $-0,044$ & $-0,115$ & $-0,088$ & $-0,098$ & $-0,100$ & $-0,110$ & $-0,070$ & $-0,052$ & $-0,059$ \\
\hline Lüksemburg & $-0,117$ & $-0,156$ & $-0,128$ & $-0,148$ & $-0,078$ & $-0,134$ & $-0,076$ & $-0,153$ & $-0,130$ & $-0,113$ \\
\hline Macaristan & $-0,055$ & $-0,065$ & $-0,091$ & $-0,073$ & $-0,086$ & $-0,028$ & $-0,083$ & $-0,057$ & $-0,121$ & $-0,122$ \\
\hline Malta & $-0,065$ & $-0,125$ & $-0,116$ & $-0,016$ & $-0,080$ & $-0,089$ & $-0,021$ & $-0,162$ & $-0,131$ & $-0,082$ \\
\hline Hollanda & $-0,130$ & $-0,148$ & $-0,138$ & $-0,152$ & $-0,084$ & $-0,125$ & $-0,144$ & $-0,134$ & $-0,115$ & $-0,119$ \\
\hline Avusturya & $-0,109$ & $-0,123$ & $-0,090$ & $-0,120$ & $-0,127$ & $-0,134$ & $-0,139$ & $-0,148$ & $-0,076$ & $-0,108$ \\
\hline Polonya & $-0,069$ & $-0,038$ & $-0,096$ & $-0,053$ & $-0,088$ & $-0,007$ & $-0,052$ & $-0,092$ & $-0,098$ & $-0,080$ \\
\hline Portekiz & $-0,088$ & $-0,102$ & $-0,122$ & $-0,094$ & $-0,083$ & $-0,117$ & $-0,069$ & $-0,091$ & $-0,090$ & $-0,069$ \\
\hline Romanya & $-0,027$ & $-0,035$ & $-0,079$ & $-0,039$ & $-0,020$ & 0,000 & $-0,052$ & $-0,037$ & $-0,047$ & $-0,092$ \\
\hline Slovenya & $-0,129$ & $-0,090$ & $-0,090$ & $-0,057$ & $-0,118$ & $-0,102$ & $-0,117$ & $-0,097$ & $-0,084$ & $-0,103$ \\
\hline Slovakya & $-0,083$ & $-0,059$ & $-0,068$ & $-0,049$ & $-0,068$ & $-0,047$ & $-0,082$ & $-0,053$ & $-0,117$ & $-0,128$ \\
\hline Finlandiya & $-0,141$ & $-0,122$ & $-0,152$ & $-0,136$ & $-0,125$ & $-0,134$ & $-0,132$ & $-0,148$ & $-0,091$ & $-0,106$ \\
\hline İsveç & $-0,150$ & $-0,145$ & $-0,156$ & $-0,137$ & $-0,141$ & $-0,124$ & $-0,131$ & $-0,155$ & $-0,126$ & $-0,110$ \\
\hline Birleşik Krallık & $-0,133$ & $-0,143$ & $-0,094$ & $-0,134$ & $-0,104$ & $-0,105$ & $-0,132$ & $-0,099$ & $-0,134$ & $-0,146$ \\
\hline İzlanda & $-0,117$ & $-0,139$ & $-0,159$ & $-0,139$ & $-0,117$ & $-0,135$ & $-0,147$ & $-0,076$ & $-0,135$ & $-0,059$ \\
\hline
\end{tabular}


Ejder AYÇİN, Enver ÇAKIN

\begin{tabular}{|l|l|l|l|l|l|l|l|l|l|l|}
\hline İsrail & $-0,091$ & $-0,108$ & $-0,088$ & $-0,068$ & $-0,175$ & $-0,095$ & $-0,136$ & $-0,116$ & $-0,158$ & $-0,120$ \\
\hline Makedonya & $-0,046$ & $-0,073$ & $-0,050$ & $-0,053$ & $-0,073$ & $-0,076$ & $-0,058$ & $-0,025$ & $-0,012$ & $-0,070$ \\
\hline Norveç & $-0,128$ & $-0,128$ & $-0,129$ & $-0,157$ & $-0,120$ & $-0,132$ & $-0,134$ & $-0,063$ & $-0,100$ & $-0,077$ \\
\hline Sırbistan & $-0,072$ & $-0,042$ & $-0,027$ & $-0,062$ & $-0,116$ & $-0,093$ & $-0,103$ & $-0,039$ & $-0,099$ & $-0,086$ \\
\hline İsviçre & $-0,160$ & $-0,168$ & $-0,129$ & $-0,142$ & $-0,170$ & $-0,161$ & $-0,137$ & $-0,159$ & $-0,116$ & $-0,135$ \\
\hline Ukrayna & $-0,107$ & $-0,028$ & $-0,008$ & $-0,031$ & $-0,052$ & $-0,029$ & $-0,017$ & $-0,024$ & $-0,086$ & $-0,054$ \\
\hline Türkiye & $-0,041$ & $-0,047$ & $-0,088$ & $-0,080$ & $-0,121$ & $-0,103$ & $-0,078$ & $-0,017$ & $-0,018$ & $-0,081$ \\
\hline ej & 0,970 & 0,955 & 0,965 & 0,955 & 0,970 & 0,948 & 0,964 & 0,949 & 0,973 & 0,980 \\
\hline
\end{tabular}

Entropi yönteminin son aşamasında Tablo 4'teki $\left(e_{j}\right)$ değerleri ve Eşitlik (4)-(5)'ten yararlanılarak farklış̧̧ma dereceleri ve kriter ağıllıkları bulunur. Elde edilen sonuçlar Tablo 5'te gösterilmiştir.

\section{Tablo 5. Entropi Yöntemiyle Hesaplanan Kriter Ağırlıkları}

\begin{tabular}{|l|l|l|l|l|l|l|l|l|l|l|}
\hline KRİTERLER & K1 & $\mathbf{K} 2$ & $\mathbf{K 3}$ & $\mathbf{K} 4$ & $\mathbf{K 5}$ & $\mathbf{K 6}$ & $\mathbf{K} 7$ & $\mathbf{K 8}$ & $\mathbf{K}$ 9 & K10 \\
\hline $\mathbf{d j}$ & 0,030 & 0,045 & 0,035 & 0,045 & 0,030 & 0,052 & 0,035 & 0,051 & 0,027 & 0,020 \\
\hline $\mathbf{w j}$ & $\mathbf{0 , 0 8 1}$ & $\mathbf{0 , 1 2 1}$ & $\mathbf{0 , 0 9 4}$ & $\mathbf{0 , 1 2 1}$ & $\mathbf{0 , 0 8 1}$ & $\mathbf{0 , 1 4 1}$ & $\mathbf{0 , 0 9 5}$ & $\mathbf{0 , 1 3 9}$ & $\mathbf{0 , 0 7 2}$ & $\mathbf{0 , 0 5 5}$ \\
\hline
\end{tabular}

Tablo 5'te yer alan Entropi yöntemi sonuçlarına göre en önemli kriterin yenilikçilik (K6) olduğu, bu kriteri sırasıyla fikri varlıklar (K8) ile finansman ve destekler (K4) kriterlerinin izlediği; en az öneme sahip kriterlerin ise sırasıyla satışların etkisi (K10), istihdam etkisi (K9) ve insan kaynakları (K1) kriterleri olduğu görülmektedir.

\subsection{MABAC Yöntemi İle Ülkelerin İnovasyon Performanslarının Değerlendirilmesi}

MABAC yöntemi ile çözüm yapıllırken diğer ÇKKV yöntemlerinde olduğu gibi öncelikle ilk olarak normalizasyon işlemi yapılır. Tablo 2'de yer alan karar matrisindeki değerler, tüm kriterler maksimizasyon yönlü olduğundan Eşitlik (8)'den yararlanılarak normalize edilir. Normalize edilmiş karar matrisi Tablo 6'da gösterilmiştir.

Tablo 6. MABAC Yöntemi Normalize Edilmiş Karar Matrisi

\begin{tabular}{|l|l|l|l|l|l|l|l|l|l|l|}
\hline ÜLKE/KRİTER & K1 & $\mathbf{K} 2$ & $\mathbf{K} 3$ & $\mathbf{K} 4$ & $\mathbf{K 5}$ & $\mathbf{K 6}$ & $\mathbf{K} 7$ & $\mathbf{K 8}$ & $\mathbf{K 9}$ & $\mathbf{K 1 0}$ \\
\hline Belçika & 0,489 & 0,735 & 0,533 & 0,691 & 0,591 & 0,863 & 1,000 & 0,472 & 0,403 & 0,486 \\
\hline Bulgaristan & 0,197 & 0,041 & 0,252 & 0,105 & 0,192 & 0,076 & 0,147 & 0,487 & 0,537 & 0,072 \\
\hline Çek Cumhuriyeti & 0,332 & 0,262 & 0,388 & 0,300 & 0,446 & 0,461 & 0,447 & 0,340 & 0,608 & 0,677 \\
\hline Danimarka & 0,922 & 0,803 & 1,000 & 0,712 & 0,471 & 0,599 & 0,800 & 0,993 & 0,527 & 0,485 \\
\hline Almanya & 0,421 & 0,359 & 0,499 & 0,707 & 0,700 & 0,817 & 0,759 & 0,878 & 0,526 & 0,872 \\
\hline Estonya & 0,474 & 0,346 & 0,515 & 0,615 & 0,269 & 0,151 & 0,434 & 0,644 & 0,381 & 0,365 \\
\hline İrlanda & 0,680 & 0,604 & 0,478 & 0,513 & 0,395 & 0,910 & 0,523 & 0,240 & 0,887 & 1,000 \\
\hline Yunanistan & 0,289 & 0,349 & 0,187 & 0,236 & 0,208 & 0,630 & 0,530 & 0,165 & 0,349 & 0,196 \\
\hline İspanya & 0,557 & 0,333 & 0,533 & 0,545 & 0,271 & 0,225 & 0,388 & 0,401 & 0,469 & 0,470 \\
\hline
\end{tabular}




\section{Ülkelerin Ínovasyon Performanslarının Ölçümünde Entropi ve MA...}

\begin{tabular}{|c|c|c|c|c|c|c|c|c|c|c|}
\hline Fransa & 0,589 & 0,543 & 0,503 & 1,000 & 0,367 & 0,650 & 0,604 & 0,488 & 0,479 & 0,780 \\
\hline Hirvatistan & 0,146 & 0,087 & 0,189 & 0,226 & 0,411 & 0,386 & 0,374 & 0,131 & 0,348 & 0,000 \\
\hline İtalya & 200 & 0,336 & 0,305 & 0,359 & 0,222 & 0,565 & 0,309 & 0,598 & 0,380 & 0,474 \\
\hline Kibris & 0,429 & 0,420 & 0,214 & 0,265 & 0,205 & 0,541 & 0,330 & 0,668 & 0,304 & 0,465 \\
\hline Letonya & 0,268 & 0,146 & 0,524 & 0,691 & 0,105 & 0,079 & 0,226 & 0,250 & 0,488 & 0,184 \\
\hline Litvanya & 435 & 0,075 & 0,614 & 0,391 & 0,394 & 0,496 & 0,607 & 0,267 & 0,184 & 0,093 \\
\hline Lüksemburg & 0,598 & 0,883 & 0,720 & 0,876 & 0,276 & 0,761 & 0,346 & 0,912 & 0,740 & 0,579 \\
\hline Macaristan &, 150 & 0,192 & 0,434 & 0,294 & 0,322 & 0,094 & 0,394 & 0,191 & 0,660 & 0,680 \\
\hline Malta & 0,206 & 0,605 & 0,617 & 0,000 & 0,288 & 0,423 & 0,015 & 1,000 & 0,746 & 0,283 \\
\hline Hollanda & 0,710 & 0,807 & 0,802 & 0,917 & 0,312 & 0,681 & 0,930 & 0,745 & 0,609 & 0,648 \\
\hline Avusturya & 0,524 & 0,589 & 0,426 & 0,631 & 0,596 & 0,759 & 0,880 & 0,869 & 0,331 & 0,529 \\
\hline & 0,232 & & & 0,178 & & 0,018 & 0,184 & 0,415 & & 0,270 \\
\hline Porte & 0,362 & 0,430 & 0,666 & 0,433 & 0,304 & 0,621 & 0,294 & 0,408 & 0,425 & 0,172 \\
\hline Rom & 0,000 & 0,032 & 0,352 & 0,103 & 0,000 & 0,000 & 0,185 & 0,085 & 0,157 & 0,376 \\
\hline & 0,696 & & 0,431 & 0,197 & 0,529 & 0,512 & 0,675 & 0,451 & 0,386 & 0,484 \\
\hline Slovakya & 0,328 & 0,153 & 0,285 & 0,154 & 0,219 & 0,181 & 0,384 & 0,167 & 0,628 & 0,740 \\
\hline Finlandiya & 0,816 & 0,585 & 0,927 & 0,769 & 0,585 & 0,757 & 0,808 & 0,873 & 0,431 & 0,509 \\
\hline İsveç & 0,897 & 0,778 & 0,962 & 0,778 & 0,708 & 0,679 & 0,798 & 0,935 & 0,700 & 0,554 \\
\hline Birleşik Krallık & 0,739 & 0,761 & 0,455 & 0,749 & 0,436 & 0,532 & 0,814 & 0,460 & 0,770 & 0,956 \\
\hline İzlanda & 0,597 & 0,723 & 1,000 & 0,794 & 0,526 & 0,769 & 0,966 & 0,306 & 0,783 & 0,093 \\
\hline İsrail & 0,386 & 0,472 & 0,412 & 0,263 & 1,000 & 0,464 & 0,856 & 0,591 & 1,000 & 0,652 \\
\hline Makedonya & 0,095 & 0,235 & 0,186 & 0,175 & 0,245 & 0,342 & 0,225 & 0,033 & 0,000 & 0,185 \\
\hline Norveç & 0,695 & 0,628 & 0,722 & 0,964 & 0,548 & 0,745 & 0,832 & 0,227 & 0,495 & 0,237 \\
\hline Surbistan & 0,253 & 0,065 & 0,074 & 0,229 & 0,516 & 0,450 & 0,554 & 0,097 & 0,487 & 0,322 \\
\hline İsviçre & 1,000 & 1,000 & 0,727 & 0,822 & 0,961 & 1,000 & 0,862 & 0,977 & 0,622 & 0,827 \\
\hline Ukrayna & 0,510 & 0,000 & 0,000 & 0,064 & 0,137 & 0,099 & 0,000 & 0,027 & 0,398 & 0,057 \\
\hline Türkiye & 0,070 & 0,091 & 0,413 & 0,340 & 0,553 & 0,522 & 0,355 & 0,000 & 0,024 & 0,275 \\
\hline
\end{tabular}

Normalize edilen karar matrisi Eşitlik (10)'dan yararlanılarak, uygulamanın ilk aşamasında Entropi yöntemiyle Tablo 5'te hesaplanan kriter ağırlıkları ile çarpılır ve ağırlıklandırılmış normalize karar matrisi Tablo 7'de gösterilen şekilde elde edilir.

\section{Tablo 7. Ağırlıklandırılmış Karar Matrisi}

\begin{tabular}{|l|l|l|l|l|l|l|l|l|l|l|}
\hline ÜLKE/KRITER & K1 & K2 & K3 & K4 & K5 & K6 & K7 & K8 & K9 & K10 \\
\hline Belçika & 0,120 & 0,210 & 0,144 & 0,205 & 0,128 & 0,263 & 0,189 & 0,205 & 0,101 & 0,082 \\
\hline Bulgaristan & 0,096 & 0,126 & 0,118 & 0,134 & 0,096 & 0,152 & 0,109 & 0,207 & 0,111 & 0,059 \\
\hline Çek Cumhuriyeti & 0,107 & 0,152 & 0,131 & 0,158 & 0,117 & 0,206 & 0,137 & 0,186 & 0,116 & 0,093 \\
\hline Danimarka & 0,155 & 0,218 & 0,188 & 0,208 & 0,119 & 0,226 & 0,170 & 0,277 & 0,110 & 0,082 \\
\hline Almanya & 0,114 & 0,164 & 0,141 & 0,207 & 0,137 & 0,257 & 0,167 & 0,261 & 0,110 & 0,103 \\
\hline Estonya & 0,119 & 0,163 & 0,143 & 0,196 & 0,102 & 0,163 & 0,136 & 0,229 & 0,100 & 0,075 \\
\hline İrlanda & 0,135 & 0,194 & 0,139 & 0,184 & 0,112 & 0,270 & 0,144 & 0,172 & 0,136 & 0,110 \\
\hline Yunanistan & 0,104 & 0,163 & 0,112 & 0,150 & 0,097 & 0,230 & 0,145 & 0,162 & 0,097 & 0,066 \\
\hline
\end{tabular}


Ejder AYÇİN, Enver ÇAKIN

\begin{tabular}{|c|c|c|c|c|c|c|c|c|c|c|}
\hline İspanya & 0,125 & 0,161 & 0,144 & 0,188 & 0,102 & 0,173 & 0,131 & 0,195 & 0,106 & 0,081 \\
\hline Fransa & 0,128 & 0,186 & 0,142 & 0,243 & 0,110 & 0,233 & 0,152 & 0,207 & 0,107 & 0,098 \\
\hline Hirvatistan & 092 & 0,131 & 0,112 & 0,149 & 0,114 & 0,196 & & 0,157 & & 0,055 \\
\hline İtalya & 097 & 0,161 & 0,123 & 0,165 & 0,098 & 0,221 & 0,124 & 0,222 & 0,100 & 0,081 \\
\hline Kıbris &, 115 & 0,171 & 0,114 & 0,154 & 0,097 & 0,218 & 0,126 & 0,232 & 0,094 & 0,081 \\
\hline Letonya & 0,102 & 0,138 & 0,143 & 0,205 & 0,089 & 0,152 & & 0,174 & 0,107 & 0,065 \\
\hline Litva & 0,116 & 0,130 & 0,152 & 0,169 & 0,112 & 0,211 & 0,152 & 0,176 & 0,086 & 0,060 \\
\hline Lüksemburg & 0,129 & 0,227 & 0,162 & 0,228 & 0,103 & 0,249 & 0,127 & 0,266 & 0,126 & 0,087 \\
\hline Macaristan & 0,093 & 0,144 & 0,135 & 0,157 & 0,107 & 0,155 & 0,132 & 0,166 & 0,120 & 0,093 \\
\hline Malta & 0,097 & 0,194 & 0,152 & 0,121 & 0,104 & 0,201 & 0,096 & 0,278 & 0,126 & 0,071 \\
\hline Hollan & 0,138 & 0,218 & 0,170 & 0,233 & 0,106 & 0,238 & 0,183 & 0,243 & 0,116 & 0,091 \\
\hline Avusturya & 0,123 & 0,192 & 0,134 & 0,198 & 0,129 & 0,249 & 0,178 & 0,260 & 0,096 & 0,084 \\
\hline Polonya & 0,099 & 0,127 & 0,138 & 0,143 & 0,108 & 0,144 & 0,112 & 0,197 & 0,107 & 0,070 \\
\hline & & & & & & & & & & 0,065 \\
\hline Rom & 0,081 & 0,125 & 0,127 & 0,134 & 0,081 & 0,141 & 0,1 & 0,151 & 0,084 & 0,076 \\
\hline & & & & & & 0,214 & & 0,202 & 0,100 & 0,082 \\
\hline Slovakya & 0,107 & 0,139 & 0,121 & 0,140 & 0,098 & 0,167 & 0,131 & 0,162 & 0,118 & 0,096 \\
\hline Finland & 0,146 & 0,191 & 0,181 & 0,215 & 0,128 & 0,248 & 0,171 & 0,260 & 0,103 & 0,083 \\
\hline İsveç & & & & 0,216 & & 0,237 & & 0,269 & 0,123 & 0,086 \\
\hline Birleşik Krallık & 0,140 & 0,213 & 0,137 & 0,212 & 0,116 & 0,217 & 0,172 & 0,203 & 0,128 & 0,108 \\
\hline İzlanda & & 0,208 & 0,188 & 0,218 & 0,123 & 0,250 & 0,186 & 0,182 & 0,129 & 0,060 \\
\hline İsrail & 0,112 & 0,178 & 0,133 & 0,153 & 0,161 & 0,207 & 0,176 & 0,221 & 0,144 & 0,091 \\
\hline Maked & 0,088 & 0,149 & 0,112 & 0,143 & 0,100 & 0,190 & 0,116 & 0,144 & 0,072 & 0,065 \\
\hline Norveç & & 0,197 & 0,162 & 0,239 & 0,125 & 0,247 & 0,173 & 0,171 & 0,108 & 0,068 \\
\hline Sirbistan & 0,101 & 0,129 & 0,101 & 0,149 & 0,122 & 0,205 & 0,147 & 0,153 & 0,107 & 0,073 \\
\hline İsviçre & 0,161 & 0,241 & 0,163 & 0,221 & 0,158 & 0,283 & 0,176 & 0,275 & 0,117 & 0,101 \\
\hline Ukrayna & 0,122 & 0,121 & 0,094 & 0,129 & 0,092 & 0,155 & 0,095 & 0,143 & 0,101 & 0,058 \\
\hline Türkiye & 0,086 & 0,132 & 0,133 & 0,163 & 0,125 & 0,215 & 0,128 & 0,139 & 0,074 & 0,070 \\
\hline
\end{tabular}

MABAC yönteminin bir sonraki adımında sınır yakınlık alanı değerleri Eşitlik (11)'den yararlanılarak hesaplanır. Hesaplanan bu değerler ile oluşturulan sınır yakınlık alanı matrisi Tablo 8'de gösterilmiştir.

Tablo 8. Sınır Yakınlık Alanı Matrisi

\begin{tabular}{|l|l|l|l|l|l|l|l|l|l|l|}
\hline KRİTERLER & K1 & K2 & K3 & K4 & K5 & K6 & K7 & K8 & K9 & K10 \\
\hline Gi & 0,115 & 0,167 & 0,139 & 0,176 & 0,112 & 0,208 & 0,142 & 0,199 & 0,107 & 0,078 \\
\hline
\end{tabular}

Tablo 8'deki her kriter için hesaplanan sınır yakınlık alanına, her bir ülke değerinin uzaklıkları Eşitlik (14)'ten yararlanılarak hesaplanır. Sınır yakınlık alanına olan uzaklıklar matrisi Tablo 9'de gösterilmiştir. 
Tablo 9. Sınır Yakınlık Alanına Uzaklıklar

\begin{tabular}{|c|c|c|c|c|c|c|c|c|c|c|}
\hline ÜLKE/KRİTER & K1 & K2 & K3 & K4 & K5 & K6 & K7 & K8 & K9 & K10 \\
\hline Belçika & 0,005 & 0,042 & 0,005 & 0,030 & 0,016 & 0,056 & 0,048 & 0,005 & $-0,005$ & 0,004 \\
\hline Bulgaristan & $-0,019$ & $-0,042$ & $-0,021$ & $-0,041$ & $-0,016$ & $-0,056$ & $-0,033$ & 0,007 & 0,004 & $-0,019$ \\
\hline Çek Cumhuriyeti & $-0,008$ & $-0,015$ & $-0,008$ & $-0,018$ & 0,004 & $-0,001$ & $-0,005$ & $-0,013$ & 0,010 & 0,014 \\
\hline Danimarka & 0,040 & 0,050 & 0,050 & 0,032 & 0,006 & 0,018 & 0,029 & 0,078 & 0,004 & 0,003 \\
\hline Almanya & $-0,001$ & $-0,003$ & 0,002 & 0,032 & 0,025 & 0,049 & 0,025 & 0,062 & 0,004 & 0,025 \\
\hline Estonya & 0,003 & $-0,005$ & 0,004 & 0,021 & $-0,010$ & $-0,045$ & $-0,006$ & 0,029 & $-0,007$ & $-0,003$ \\
\hline İrlanda & 0,020 & 0,026 & 0,000 & 0,008 & 0,000 & 0,062 & 0,002 & $-0,027$ & 0,030 & 0,032 \\
\hline Yunanistan & $-0,011$ & $-0,004$ & $-0,027$ & $-0,026$ & $-0,015$ & 0,023 & 0,003 & $-0,037$ & $-0,009$ & $-0,012$ \\
\hline İspanya & 0,010 & $-0,006$ & 0,005 & 0,012 & $-0,010$ & $-0,035$ & $-0,010$ & $-0,005$ & $-0,001$ & 0,003 \\
\hline Fransa & 0,013 & 0,019 & 0,003 & 0,067 & $-0,002$ & 0,025 & 0,010 & 0,007 & 0,000 & 0,020 \\
\hline Hirvatistan & $-0,023$ & $-0,036$ & $-0,027$ & $-0,027$ & 0,002 & $-0,012$ & $-0,012$ & $-0,042$ & $-0,009$ & $-0,023$ \\
\hline İtalya & $-0,019$ & $-0,006$ & $-0,016$ & $-0,011$ & $-0,014$ & 0,013 & $-0,018$ & 0,023 & $-0,007$ & 0,003 \\
\hline Kibris & 0,000 & 0,004 & $-0,024$ & $-0,022$ & $-0,015$ & 0,010 & $-0,016$ & 0,032 & $-0,012$ & 0,002 \\
\hline Letonya & $-0,013$ & $-0,029$ & 0,005 & 0,030 & $-0,023$ & $-0,055$ & $-0,026$ & $-0,026$ & 0,001 & $-0,013$ \\
\hline Litvanya & 0,000 & $-0,037$ & 0,013 & $-0,007$ & 0,000 & 0,004 & 0,010 & $-0,023$ & $-0,021$ & $-0,018$ \\
\hline Lüksemburg & 0,013 & 0,060 & 0,023 & 0,052 & $-0,009$ & 0,041 & $-0,014$ & 0,066 & 0,019 & 0,009 \\
\hline Macaristan & $-0,023$ & $-0,023$ & $-0,004$ & $-0,019$ & $-0,006$ & $-0,053$ & $-0,010$ & $-0,034$ & 0,013 & 0,014 \\
\hline Malta & $-0,018$ & 0,026 & 0,013 & $-0,054$ & $-0,008$ & $-0,007$ & $-0,046$ & 0,079 & 0,019 & $-0,008$ \\
\hline Hollanda & 0,022 & 0,051 & 0,031 & 0,057 & $-0,006$ & 0,030 & 0,041 & 0,043 & 0,010 & 0,012 \\
\hline Avusturya & 0,008 & 0,025 & $-0,005$ & 0,022 & 0,017 & 0,041 & 0,036 & 0,060 & $-0,011$ & 0,006 \\
\hline Polonya & $-0,016$ & $-0,041$ & 0,000 & $-0,033$ & $-0,005$ & $-0,064$ & $-0,030$ & $-0,003$ & 0,000 & $-0,008$ \\
\hline Portekiz & $-0,006$ & 0,005 & 0,018 & $-0,002$ & $-0,007$ & 0,021 & $-0,019$ & $-0,004$ & $-0,004$ & $-0,014$ \\
\hline Romanya & $-0,035$ & $-0,043$ & $-0,012$ & $-0,042$ & $-0,032$ & $-0,066$ & $-0,030$ & $-0,049$ & $-0,023$ & $-0,003$ \\
\hline Slovenya & 0,021 & $-0,004$ & $-0,004$ & $-0,030$ & 0,011 & 0,006 & 0,017 & 0,002 & $-0,007$ & 0,003 \\
\hline Slovakya & $-0,008$ & $-0,028$ & $-0,018$ & $-0,036$ & $-0,014$ & $-0,041$ & $-0,011$ & $-0,037$ & 0,011 & 0,018 \\
\hline Finlandiya & 0,031 & 0,024 & 0,043 & 0,039 & 0,016 & 0,041 & 0,029 & 0,061 & $-0,003$ & 0,005 \\
\hline İsveç & 0,038 & 0,047 & 0,046 & 0,040 & 0,026 & 0,029 & 0,028 & 0,070 & 0,016 & 0,007 \\
\hline Birleşik Krallık & 0,025 & 0,045 & $-0,002$ & 0,037 & 0,004 & 0,009 & 0,030 & 0,004 & 0,021 & 0,029 \\
\hline İzlanda & 0,013 & 0,041 & 0,050 & 0,042 & 0,011 & 0,042 & 0,044 & $-0,018$ & 0,022 & $-0,018$ \\
\hline İsrail & $-0,004$ & 0,011 & $-0,006$ & $-0,022$ & 0,049 & $-0,001$ & 0,034 & 0,022 & 0,038 & 0,013 \\
\hline Makedonya & $-0,027$ & $-0,018$ & $-0,027$ & $-0,033$ & $-0,012$ & $-0,018$ & $-0,026$ & $-0,056$ & $-0,034$ & $-0,013$ \\
\hline Norveç & 0,021 & 0,029 & 0,023 & 0,063 & 0,013 & 0,039 & 0,032 & $-0,029$ & 0,001 & $-0,010$ \\
\hline Sirbistan & $-0,014$ & $-0,039$ & $-0,038$ & $-0,026$ & 0,010 & $-0,003$ & 0,005 & $-0,047$ & 0,001 & $-0,005$ \\
\hline İsviçre & 0,046 & 0,074 & 0,024 & 0,046 & 0,046 & 0,075 & 0,035 & 0,075 & 0,010 & 0,022 \\
\hline Ukrayna & 0,006 & $-0,047$ & $-0,045$ & $-0,046$ & $-0,020$ & $-0,052$ & $-0,047$ & $-0,057$ & $-0,006$ & $-0,020$ \\
\hline Türkiye & $-0,029$ & $-0,035$ & $-0,006$ & $-0,013$ & 0,013 & 0,007 & $-0,013$ & $-0,060$ & $-0,033$ & $-0,008$ \\
\hline
\end{tabular}

MABAC yönteminde son aşamasında, Tablo 9'daki sınır yakınlık alanına uzaklıklar kullanılarak, ülkelerin kriter fonksiyonları Eşitlik (16)'dan yararlanılarak hesaplanır. Hesaplanan bu değerler ve ülkelerin inovasyon performanslarına ilişkin bir sıralama Tablo 10'da gösterilmiştir. 
Tablo 10. $S_{i}$ Değerleri ve Ülkelerin İnovasyon Performanslarına Göre Siralamas1

\begin{tabular}{|l|c|c|}
\hline ÜLKE/KRİTER & Si & Siralama \\
\hline Belçika & 0,205 & 9 \\
\hline Bulgaristan & $-0,235$ & 33 \\
\hline Çek Cumhuriyeti & $-0,040$ & 21 \\
\hline Danimarka & $\mathbf{0 , 3 1 0}$ & $\mathbf{3}$ \\
\hline Almanya & 0,219 & 8 \\
\hline Estonya & $-0,019$ & 19 \\
\hline İrlanda & 0,154 & 14 \\
\hline Yunanistan & $-0,117$ & 25 \\
\hline İspanya & $-0,036$ & 20 \\
\hline Fransa & 0,163 & 13 \\
\hline Hırvatistan & $-0,209$ & 32 \\
\hline İtalya & $-0,050$ & 23 \\
\hline Kibris & $-0,041$ & 22 \\
\hline Letonya & $-0,150$ & 27 \\
\hline Litvanya & $-0,079$ & 24 \\
\hline Lüksemburg & 0,261 & 6 \\
\hline Macaristan & $-0,143$ & 26 \\
\hline Malta & $-0,003$ & 17 \\
\hline Hollanda & 0,291 & 4 \\
\hline Avusturya & 0,200 & 11 \\
\hline Polonya & $-0,199$ & 31 \\
\hline Portekiz & $-0,010$ & 18 \\
\hline Romanya & $-0,332$ & 35 \\
\hline Slovenya & 0,016 & 16 \\
\hline Slovakya & $-0,164$ & 29 \\
\hline Finlandiya & 0,285 & 5 \\
\hline İsveç & $\mathbf{0 , 3 4 8}$ & $\mathbf{2}$ \\
\hline Birleşik Krallık & 0,202 & 10 \\
\hline İzlanda & 0,230 & 7 \\
\hline İsrail & 0,133 & 15 \\
\hline Makedonya & $-0,264$ & 34 \\
\hline Norveç & 0,182 & 12 \\
\hline Sırbistan & $-0,156$ & 28 \\
\hline İsviçre & $\mathbf{0 , 4 5 3}$ & $\mathbf{1}$ \\
\hline Ukrayna & $-0,334$ & 36 \\
\hline Türkiye & $-0,177$ & 30 \\
\hline & & \\
\hline
\end{tabular}

Tablo 10 'da gösterilen sonuçlara göre; inovasyon performansı en iyi olan ülkenin İsviçre olduğu, İsveç ve Danimarka’nın sırasıyla İsviçre'yi takip ettiği 
görülmektedir. İnovasyon performansı en düşük olan ülkeler ise sırasıyla Ukrayna, Romanya ve Makedonya olarak belirlenmiştir.

\section{Sonuç ve Öneriler}

Ülkeler sürdürülebilir bir büyüme sağlanması, toplumsal refahın yükseltilmesi ve ülkede yaşayan insanların yaşam kalitelerinin artırılması gibi nedenlerden dolayı inovasyonu bir kalkınma aracı olarak görmektedirler. Bu doğrultuda kendi teknolojisini üretip, diğer ülkeler karşısında öne geçmek isteyen ülkeler için inovasyon kavramı oldukça önem arz etmektedir. Son yıllarda ülke kaynaklarının önemli bölümlerinin $\mathrm{Ar}-\mathrm{Ge}$ ve inovasyon faaliyetlerine ayrılması ile, bu faaliyetlerin sonuca odaklı olup olmadıklarının tespit edilmesi ve ülkelerin diğer ülkeler karşısındaki durumlarını görebilmeleri bir diğer ifadeyle ülkelerin inovasyon faaliyetlerinin performans ölçümünün yapılması önemli bir konu haline gelmiştir.

Ülkeler için oldukça önem arz eden inovasyon performansının ölçümünün yapılması bu çalışmanın çıkış noktasını oluşturmuş ve bu doğrultuda performans ölçümü ile ilgili son yıllarda sıklıkla kullanılmakta olan ÇKKV yöntemlerinden ikisi bütünleşik olarak kullanılarak, bir uygulama gerçekleştirilmiştir. İnovasyon performans kriterleri, Avrupa İnovasyon Karnesi kapsaminda yer alan bir rapordan yararlanılarak belirlendikten sonra, bu kriterlerin önem ağıllıkları objektif bir ağırlıklandırma yöntemi olan Entropi ile hesaplanmıştır. Entropi yöntemi sonuçlarına göre en önemli kriterler sırasıyla yenilikçilik, fikri varlıklar, finansman ve destekler; en az öneme sahip kriterlerin ise sırasıyla satışların etkileri, istihdam etkileri ve insan kaynakları olarak belirlenmiştir. Uygulama kapsamında yer alan otuz altı ülkenin inovasyon performanslarına göre sıralamasının yapılması için bir diğer ÇKKV karar verme yöntemi olan MABAC'tan yararlanılmıstır. MABAC yöntemi sonuçlarına göre inovasyon performansı en yüksek olan ülkeler sırasıyla İsviçre, İsveç ve Danimarka, en düşük olan ülkeler ise Ukrayna, Romanya ve Makedonya olarak belirlenmiştir. Uygulama sonuçları Entropi ve MABAC yöntemlerinden oluşan bütünleşik bir uygulama modelinin, inovasyon performansının ölçülmesinde kullanılabileceğini göstermiştir.

Gerek uluslararası gerekse de ulusal literatürde inovasyon performansının MABAC yöntemi ile değerlendirilmesine yönelik herhangi bir çalışmaya rastlanılmaması bakımından, mevcut çalışmanın literatüre katkı sağlayacağı düşünülmektedir. Gelecek çalışmalarda farklı ÇKKV yöntemleri ile uygulamalar gerçekleştirilerek, elde edilen sonuçlar karşılaştırılabilir. Ayrıca inovasyon performansının ölçülmesinde daha farklı kriterler göz önüne alınabilir, kriter ağırlıklarına yönelik değerlendirmelerin Entropi'den farklı yöntemler kullanılarak yapılabileceği çalışmalara yer verilebilir. 


\section{Kaynakça}

Abbasi, F., Hajihoseini, H. ve Haukka, S. (2010). "Use of virtual index for measuring efficiency of innovation systems: a cross-country study", International Journal of Technology Management \& Sustainable Development, 9(3), 195-212.

Apokin, A. ve Ipatova, I. (2016). "How R\&D Expenditures Influence Total Factor Productivity and Technical Efficiency?", Higher School of Economics Research Paper No. 128/EC/2016.

Aydın, H.İ. ve Yalçınkaya, Ö. (2016). “Ar-Ge Yatırımlarının Toplam Faktör Verimliliği Üzerindeki Etkileri: OECD Ülkeleri Üzerinde Panel Veri Analizi (1994-2014)", Pamukkale Üniversitesi Sosyal Bilimler Enstitüsü Dergisi, 26, 178-196

Bayraktutan, Y. ve Kethudaoğlu, F. (2017). “Ar-Ge ve İktisadi Büyüme İlişkisi: OECD Örneği”, Uluslararası Sosyal Araştırmalar Dergisi, 10(53), 1-16

Božanić, D. A., Pamučar, D. S. ve Karović, S. M. (2016). "Use of the fuzzy AHP-MABAC hybrid model in ranking potential locations for preparing laying-up positions", Vojnotehnički Glasnik / Military Technical Courier, 64(3), 705-729.

Çakır, S. ve Perçin, S. (2013). "AB ülkelerinde bütünleşik Entropi ağırlıkTOPSIS yöntemiyle Ar-Ge performansinın ölçülmesi”, Uludăg Üniversitesi İktisadi ve İdari Bilimler Fakültesi Dergisi, 32(1), 77-95.

Çatı, K., Eş, A. ve Özevin, O. (2017). "Futbol takımlarının finansal ve sportif etkinliklerinin Entropi ve TOPSIS yöntemiyle analiz edilmesi: Avrupa'nın 5 büyük ligi ve süper lig üzerine bir uygulama", Uluslararası Yönetim İktisat ve Issletme Dergisi. 13(1), 199222.

Chaghooshi, A. J., Fathi, M. R. ve Kashef, M. (2012). "Integration of fuzzy Shannon's Entropy with fuzzy TOPSIS for industrial robotic system selection", Journal of Industrial Engineering and Management, 5(1), 102-114.

Chen, C. P., Yang, C. H. ve Hu, J. L. (2011). "An international comparison of R\&D efficiency of multiple innovative outputs: The role of the national innovation system", Innovation: Management, Policy \& Practice, 13, 341-360.

Chen, G. (2017). "An Entropy-TOPSIS method for evaluation innovation performance of the high-tech industry", Boletin Técnico, 55(3), 155163. 
Elçi, Ş. (2007). Inovasyon: Kalkenma ve Rekabetin Anabtarr. INOMER: İstanbul.

Erol, İ. ve Ferrell Jr, W.(2009). "Integrated approach for reorganizing purchasing: theory and a case analysis on a Turkish company", Computers \& Industrial Engineering, 56(4), 1192-1204.

Gault, F. (2018). "Defining and measuring innovation in all sectors of the economy", Research Policy, 47, 617-622.

Ghazinoory, S., Riahi, P., Azar, A. ve Miremadi, T. (2014). "Measuring innovation performance of developing regions: learning and catchup in provinces of Iran", Technological and Economic Development of Economy. 20(3), 507-533.

Gigović, L., Pamučar, D., Božanić, D. ve Ljubojević, S. (2017). “Application of the GIS-DANP-MABAC multi-criteria model for selecting the location of wind farms: A case study of Vojvodina, Serbia", Renewable Energy, 103, 501-521.

Gömleksiz, M., Şahbaz, A. ve Mercan, B. (2017). “Toplam Faktör Verimliliğinin Belirleyicileri Üzerine Ampirik Bir İnceleme: Seçilmiş OECD Ülkeleri Örneğì", Eskişsehir Osmangąi Üniversitesi İIBF Dergisi, 12(2), 65-82

Griffith, R., Redding, S. ve Reenen, J.V. (2004). "Mapping The Two Faces of R\&D: Productivity Growth In A Panel of OECD Industries", Review of Economics and Statistics, 86(4), 883-895

Hagedoorn, J. ve Cloodt, M. (2003). "Measuring innovative performance is there an advantage in using multiple indicators", Research Policy, 32, 1365-1379.

Hung, C. C. ve Chen, L. H. (2009). "A fuzzy TOPSIS decision making model with Entropy weight under intuitionistic fuzzy environment", Proceedings of the International MultiConference of Engineers and Computer Scientists IMECS 2009, Hong Kong.

Işık, N. ve Kılınç, E.C. (2011). "Bölgesel Kalkınma'da Ar- Ge ve İnovasyonun Önemi: Karşılaştırmalı Bir Analiz", Eskişehir Osmangaæi Üniversitesi İ̈BF Dergisi, 6(2), 9- 54

İnel, M. N. ve Türker, M. V. (2016). "Ulusal inovasyon performansının ölçümü için çok nitelikli karar verme teknikleri ile bir model denemesi", Marmara Üniversitesi İktisadi ve İdari Bilimler Dergisi, 38(2), 147-166.

Katila, R. (2000). "Using patent data to measure innovation performance, International Journal of Business Performance Measurement", 2, 180-193. 
Kijek, A. ve Kijek, T. (2010). "The comparative analysis of innovation performance in the EU countries", Acta Universitatis Lodziensis Folia Oeconomica. 242, 193-204.

Konings, R. ve Louw, E. (2014). "Innovation performance of the transport sector at regional level", International Conference on Traffic and Transport Engineering - Belgrade, 27-28 November.

Korkmaz, S. (2010). "Türkiye'de Ar- Ge Yatırımları ve Ekonomik Büyüme Arasındaki İlişkinin VAR Modeli ile Analizi”, Journal of Yasar University, 20(5), 3320- 3330

Li, W., Yi, P. ve Zhang, D. (2018). "Sustainability evaluation of cities in Northeastern China using dynamic TOPSIS-Entropy methods", Sustainability. 10, 1-15.

Li, X., Wang, K., Liu, L., Xin, J., Yang, H. ve Gao, C. (2011). “Application of the Entropy weight and TOPSIS method in safety evaluation of coal mines", Procedia Engineering, 26, 2085-2091.

Mavi, R. K. ve Standing, C. (2017). "Eco-innovation analysis with DEA: an application to OECD countries", International Journal on Computer Science and Information Systems, 12(2), 133-147.

Milosavljević, M., Bursać, M. ve Tričković, G. (2018). "Selection of the railroad container terminal in Serbia based on multi criteria decision-making methods", Decision Making: Applications in Management and Engineering, 1(2), 1-15.

OECD (2005). Oslo Klavuæu: Yenilik Verilerinin Toplanması ve Yorumlanması İçin Illkeler. Avrupa Komisyonu.

Ömürbek N., Karaatll, M. ve Balc1, H. F. (2016). "Entropi temelli MAUT ve SAW yöntemleri ile otomotiv firmalarının performans değerlemesi”, Dokuz Eylül Üniversitesi İktisadi ve İdari Bilimler Fakültesi Dergisi, 31(1), 227-255.

Özdağoğlu, A., Yakut, E. ve Bahar, S. (2017). "Machine selection in a dairy product company with Entropy and SAW method integration", Dokuz Eylül Üniversitesi İktisadi ve İdari Bilimler Fakültesi Dergisi, 32(1), 341-359.

Pamučar, D. ve Ćirović, G. (2015). "The selection of transport and handling resources in logistics centers using multi-attributive border approximation area comparison (MABAC)", Expert Systems with Applications, 42(6), 3016-3028.

Pamučar, D., Petrović, I. ve Ćirović, G. (2018).” Modification of the BestWorst and MABAC methods: A novel approach based on interval- 
valued fuzzy-rough numbers", Expert Systems with Applications, 91, 89-106.

Pop, D. M. ve Pop, M. T. (2018). "Measuring the innovation of economy through global and European tools", MATEC Web of Conferences, 184, 1-5.

Roszko-Wójtowicz, E. ve Białek, J. (2016). “A multivariate approach in measuring innovation performance", Zb. rad. Ekon. fak. Rij, 34(2), 443-479.

Sadraoui, T. ve Zina, N. B. (2009). "A Dynamic Panel Data Analysis for R\&D Cooperation and Economic Growth". International Journal of Foresight and Innovation Policy, 5(4), 218- 233.

Sar1, E.B. (2017). "Endüstri İşletmelerinde Ar-Ge Projelerini Öncelik Sıralamasında Entropi Ağırlıklı TOPSIS Yöntemine Dayalı Çok Kriterli Bir Analiz", International Journal of Academic Value Studies, 3(11), $159-170$.

Sarı, E. B. (2017). “Toplam Verimli Bakım Uygulayan Bir İşletmede Bakım Personelinin Performans Değerleme Puanlarının Entropi Tabanlı VIKOR Sıralaması ile Karşılaştırılması", İşletme Bilimi Dergisi, 5(3), 59-78.

Taş, Ş., Taşar, İ. ve Açc1, Y. (2017). “Ar-Ge Harcamaları ve Ekonomik Büyüme Arasındaki İlişki: Türkiye Örneği”, Ömer Halisdemir Üniversitesi İktisadi ve İdari Bilimler Fakültesi Dergisi, 10(2), 197-206

Tiryakioğlu, M. (2007). "Araştırma Geliştirme-Ekonomik Büyüme İlişkisi: Seçilmiş OECD Ülkeleri Üzerine Uygulama”, Yüksek Lisans Tezi, Afyon Kocatepe Üniversitesi Sosyal Bilimler Enstitüsü

Vesković, S., Stević, Z., Stojić, G., Vasiljević, M. ve Milinković, S. (2018). "Evaluation of the railway management model by using a new integrated model Delphi-SWARA-MABAC", Decision Making: Applications in Management and Engineering, 1(2), 34-50.

Vujičić, M. D., Papić, M. Z. ve Blagojević, M. D. (2017). “Comparative analysis of objective techniques for criteria weighing in two MCDM methods on example of an air conditioner selection", Tebnika, 72(3), 422-429.

Wakelin, K. (2001). "Productivity Growth and R\&D Expenditure in UK Manufacturing Firms", Research Policy, 30, 1079-1090

Wang, T. C. ve Lee, H. D. (2009). "Developing a fuzzy TOPSIS approach based on subjective weights and objective weights", Expert Systems with Applications, 6(5), 8980-8985. 
Xue, Y. X., You, J. X., Lai, X. D. ve Liu, H. C. (2016). “An interval-valued intuitionistic fuzzy MABAC approach for material selection with incomplete weight information", Applied Soft Computing, 38, 703713.

Yu, S. M., Wang, J. ve Wang, J. Q. (2017). "An interval type-2 fuzzy likelihood-based MABAC approach and its application in selecting hotels on a tourism website", International Journal of Fuzzy Systems, 19(1), 47-61.

Zhang, H., Gu, C. L, Gu, L. W. ve Zhang, Y. (2011). “The evaluation of tourism destination competitiveness by TOPSIS \& information entropy-a case in the Yangtze River delta of China", Tourism Management, 32(2), 443-451.

Zhang, Y. (2015). "TOPSIS method based on entropy weight for supplier evaluation of power grid enterprise", 2nd International Conference on Education Reform and Modern Management (ERMM 2015).

Zhuparova, A. S. (2012). "Problems of measuring effectiveness of innovation performance". International Journal of Social, Behavioral, Educational, Economic, Business and Industrial Engineering, 6(6), 16011608.

Zizlavsky, O. (2016). "Innovation performance measurement: research into Czech business practice", Economic Research-Ekonomska Istraživanja, 29(1), 816-838. 